Matsuoka, S. M., J. C. Hagelin, M. A. Smith, T. F. Paragi, A. L. Sesser, and M. A. Ingle. 2019. Pathways for avian science, conservation, and management in boreal Alaska. Avian Conservation and Ecology 14(1):15. https://doi.org/10.5751/ACE-01347-140115

Copyright (C) 2019 by the author(s). Published here under license by the Resilience Alliance.

Essay, part of a Special Feature on Conservation of Boreal Birds

\title{
Pathways for avian science, conservation, and management in boreal Alaska
}

Steven M. Matsuoka ${ }^{1}$, Julie C. Hagelin ${ }^{2}$, Melanie A. Smith ${ }^{3}$, Thomas F. Paragi ${ }^{4}$, Amanda L. Sesser $^{5,6}$ and Moira A. Ingle ${ }^{2}$ ${ }^{1}$ Boreal Avian Modelling Project, Canada, ${ }^{2}$ Alaska Department of Fish and Game, Threatened, Endangered, and Diversity Program, USA, ${ }^{3}$ Audubon Alaska, USA, ${ }^{4}$ Alaska Department of Fish and Game, Division of Wildlife Conservation, USA, ${ }^{5}$ U.S. Fish and Wildlife Service, Northwest Boreal Landscape Conservation Cooperative, USA, ${ }^{6}$ University of Alaska Fairbanks, Institute of Arctic Biology, USA

ABSTRACT. Alaska contains 11\% of North America's boreal forest, the most extensive network of conservation lands on the continent, and several species of declining boreal birds, making it a critical component of boreal bird conservation and management. A variety of actions by federal, state, and environmental nongovernmental organizations (ENGOs) have important consequences for birds and boreal habitats. This is particularly true on the $86 \%$ of boreal Alaska that is managed as state and federal protected areas (45\%) and multiple-use lands (41\%). We review activities by governmental and ENGO programs as well as existing laws that directly or indirectly benefit birds in boreal Alaska, not all of which are well known to avian scientists and resource managers. In doing so we highlight examples of multiorganizational efforts that are advancing conservation and management of bird populations in the boreal region, as well as changes in government policies that influence how important statutes protecting birds can be used. We also point out several information gaps, such as identifying and mapping important areas and habitats for bird species of conservation concern, that could inform important land-use decisions in the region. Given the growing number of future challenges, in particular, the response of ecosystems and birds to a warming climate, international and cross-agency collaborations will be needed to anticipate and mitigate avian declines, as well as to maintain connectivity and ecosystem integrity across boreal landscapes.

\section{Voie à suivre pour la science, la conservation et la gestion des oiseaux dans la forêt boréale de l'Alaska}

RÉSUMÉ. L'Alaska est l'hôte de $11 \%$ de la forêt boréale d'Amérique du Nord, réseau le plus élargi de terres protégées sur le continent, et de plusieurs espèces d'oiseaux boréaux en diminution, en faisant une composante essentielle de la conservation et de la gestion des oiseaux boréaux. De très nombreuses activités menées par les gouvernements fédéral et d'État et les organisations non-gouvernementales en environnement (ONGE) ont des répercussions importantes sur les oiseaux et les habitats boréaux. Ceci est particulièrement vrai pour le $86 \%$ de l'Alaska boréal qui est géré comme aire protégée fédérale ou d'État (45\%), ou comme terre à usage polyvalent (41 \%). Nous avons passé en revue les activités de programmes gouvernementaux ou d'ONGE et les lois existantes qui favorisent directement ou indirectement les oiseaux dans la forêt boréale de l'Alaska, lesquelles ne sont pas toutes bien connues des scientifiques en ornithologie ou des gestionnaires de ressources. Nous présentons des exemples d'efforts multiorganisationnels qui font progresser la conservation et la gestion des populations d'oiseaux en région boréale, de même que les changements relatifs aux politiques gouvernementales qui influent la mesure dans laquelle la législation protégeant les oiseaux peut être utilisée. Nous mettons aussi en évidence plusieurs lacunes de connaissance, comme l'identification et la cartographie des aires et des habitats importants pour les espèces d'oiseaux préoccupantes, qui, si elles étaient comblées, permettraient de prendre d'importantes décisions quant à l'utilisation des terres dans la région. Considérant le nombre grandissant de défis à venir, tout particulièrement l'adaptation des écosystèmes et des oiseaux au réchauffement climatique, les collaborations internationales et entre agences seront nécessaires pour anticiper et amoindrir les diminutions des populations d'oiseaux, de même que pour maintenir la connectivité et l'intégrité des écosystèmes dans les paysages boréaux.

Key Words: Alaska; birds, boreal forest; conservation; government; management; nongovernment environmental organization; science

\section{INTRODUCTION}

Avian ecologists and conservationists have put forth considerable efforts to publicize the importance of Canada's boreal forests to the North American avifauna and to develop and implement science-based strategies to better conserve and manage boreal birds and their habitats in the face of increasing human land use and anthropogenic climate change (Blancher and Wells 2005, Wells 2011; see other papers in this special feature). Far less attention has been placed on Alaska's boreal region, which contains $11 \%$ of North America's boreal forests and $25 \%$ of continental boreal alpine areas (Brandt 2009). These expanses of largely remote and intact habitats support a diversity of boreal bird species with large breeding populations that often extend into boreal Canada. Although there are opportunities for proactive conservation and management of intact landscapes across boreal Alaska (Lisgo et al. 2017), there is also notable potential for economic growth and landscape change. The region contains some of the world's largest untapped deposits of metals and coal 
(Karl et al. 2016, USACE 2018, 2019), is home to $78 \%$ of the state's growing human populations $(50 \%$ regional increase since 1985; Robinson et al. 2017), and is one of the most rapidly warming areas of North America (IPCC 2014). The latter is already causing region-wide ecosystem alterations through climate-induced increases in the extent and intensity of permafrost thaw, lake and wetland drying, forests fires, and forest pest outbreaks, all of which are expected to increase in magnitude through this century (Chapin et al. 2006, Wolken et al. 2011, Roach et al. 2013).

Some landscape-level changes may already be affecting the region's birds, particularly migratory species relying on boreal wetlands for breeding and aerial insects for prey in Alaska (Handel and Sauer 2017, Sauer et al. 2017, but see Lewis et al. 2016a) and Canada (ECCC 2017). Several of these species are in decline and currently designated as threatened or of special concern under the Species at Risk Act in Canada (COSEWIC 2008, 2009, 2013, 2014, 2018, EC 2015a, b), or are considered "species of greatest conservation need" in Alaska (ADFG 2015). There are no bird species currently listed as threatened or endangered in boreal Alaska under the U.S. Endangered Species Act (ESA; Appendix 1). However, to avoid future ESA listings in boreal Alaska, greater efforts are needed to understand drivers of declining bird population trends and determine possible actions to sustain populations. This will likely require closer coordination among science and conservation groups both within boreal Alaska and between Alaska and Canada (Greenberg et al. 2011, ADFG 2015, Rosenberg et al. 2016).

State and federal government agencies and several environmental nongovernmental organizations (ENGOs) collectively play myriad roles in quantifying, monitoring, and conserving fish and wildlife populations and habitats across boreal Alaska. Roles include advocacy, managing lands, assessing environmental impacts, providing conservation funding, and conducting scientific research. Some of these activities benefit birds directly through conservation programs or legislation aimed to protect birds and their habitats. Other programs and statutes benefit birds indirectly through broader land use planning or other environmental protections. Scientific research quantifies mechanisms and drivers of change, leading to an understanding of status, trends, abundance, and distribution of populations across the landscape. However, not all programs and protective measures are well recognized by avian scientists and resource managers, and we believe there are overlooked opportunities to advance avian research and conservation in the region by better understanding the different activities of governmental and nongovernmental groups.

In this paper we examine the important government and ENGO pathways for science and for conserving and managing bird populations and habitats in boreal Alaska. First, we review the important agency and ENGO programs and U.S. laws that benefit birds in the region within three broad programmatic areas: managing lands, managing birds and their habitats, and conservation funding and science. Within each programmatic area, we (1) provide examples and case studies of how existing programs and laws have been leveraged to benefit birds, and (2) point to information or resource gaps that could be addressed to make these programs more effective in addressing bird habitat needs. We also highlight where recent changes to government policies are impacting important statutes for birds. Second, we highlight challenges and opportunities for regional bird conservation related to climate change that might benefit from avian scientists working more closely with resource managers in the future. Third, we have compiled a summary of key U.S. laws that directly and indirectly impact birds and their habitats in boreal Alaska (Appendix 1) for avian scientists and resource managers. Our paper complements a similar topic review now underway for boreal Canada (Westwood, Barker, Amos et al., unpublished manuscript), and together we hope these two papers help foster more effective and collaborative avian science, conservation, and management efforts across the many jurisdictional boundaries that span boreal North America.

\section{PATHWAYS FOR AVIAN SCIENCE, CONSERVATION, AND MANAGEMENT}

\section{Managing lands}

The most prominent role government organizations have on birds in Alaska involves land management. Eighty-six percent of boreal Alaska is public land managed by federal and state agencies $(51 \%$ federal, 35\% state; Fig. 1; ADNR 2018). ENGOs more broadly examine government land management and conservation issues across the matrix of local, state, and federal government jurisdictions as well as private and Native lands.

\section{Protected areas}

Alaska's extensive network of conservation lands is the largest for any state or province in North America (National Gap Analysis Program 2016, CCEA 2017). Approximately 45\% of Alaska's boreal region is managed as protected areas ( $42 \%$ federal, $3 \%$ state; National Gap Analysis Program 2016), including some of the largest conservation and wilderness areas on the continent. These lands were legislatively established at federal and state levels as National Parks and Preserves, National Wildlife Refuges, and Alaska State Game Refuges and Parks, with a primary purpose of protecting or conserving wildlife (often migratory birds, waterfowl, or raptors), habitats, natural landscapes, and subsistence harvests from other noncompatible land uses (Alaska National Interest Lands Conservation Act (ANILCA), Alaska Statutes [AS] 16.20, AS 41.21, see Appendix 1 for additional regulatory provisions). Many federal conservation lands support research and monitoring of naturally functioning ecosystems, trust species (including birds), and the effects of climate change on resources with the results used to adjust their management policies accordingly.

Although conservation lands afford birds a high level of protection, it is conditional, depending on state or national needs. Levels of protection often vary among, and even within conservation units, and provisions for land exchanges or natural resource developments are often included in enabling legislation (Todderud 1987; ANILCA, 75 Federal Register [FR] 29582). As an example, a $1300-\mathrm{km}$ gas pipeline project is proposed to pass through a number of federal and state conservation areas from the Arctic coast to Cook Inlet (83 FR 12002). The management direction of protected areas is formalized in conservation or management plans. Federal plans are revised every 10 to 20 years offering an opportunity to update management policies and levels 
Fig. 1. Land ownership in Alaska (National Gap Analysis Program 2016, ADNR 2018) within the Northwest Interior Forest Bird Conservation Region (U.S. NABCI 2000).

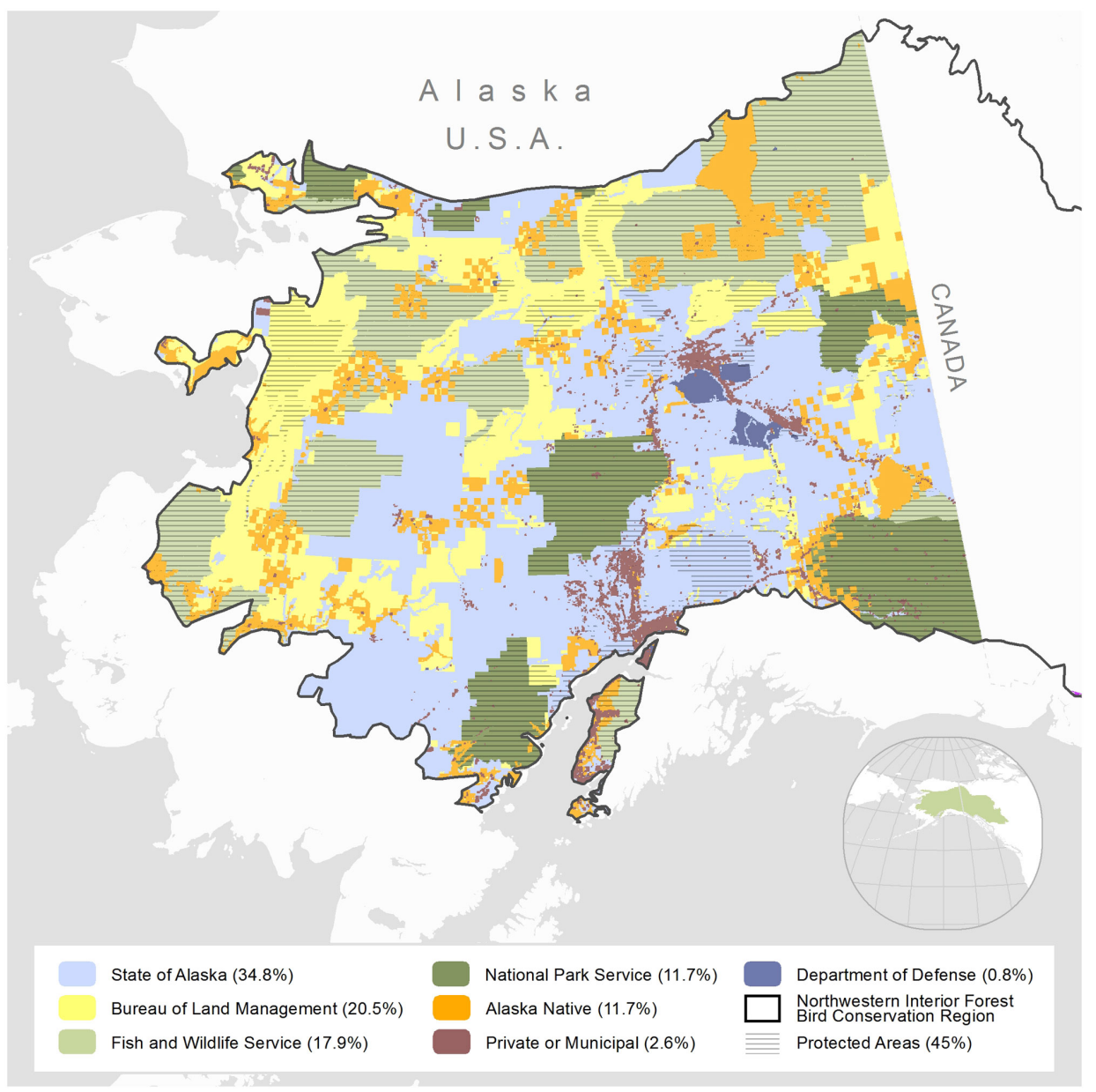

of projection to benefit birds. For example, the Arctic National Wildlife Refuge recently recommended that nearly 5-million ha (over half in the boreal) and four rivers within the Refuge be designated Wilderness and Wild and Scenic Rivers, respectively, which receive the highest federal levels of protection once approved by Congress. This was to best meet the purposes and goals of the Refuge, including protecting unaltered ecosystems and the associated populations of more than 200 species of birds using the Refuge (USFWS 2015). In a different example, the Kanuti National Wildlife Refuge revised its management policies to limit fires in a 120,000-ha area of old growth lichen-spruce to help maintain habitats for caribou (Rangifer tarandus) and mature-forest fauna, including birds (USFWS 2008).

\section{Case study: the Alaska National Interest Lands Conservation Act}

Passed in 1980, ANILCA set aside 40.5-million ha of Alaska's land to be managed by the federal government for conservation purposes and to prioritize subsistence harvests by Alaska Natives. This decision conserved boreal bird populations and habitats at an unprecedented landscape scale and stemmed from actions by the federal government and ENGOs. Prior to the passing of
ANILCA, the 1971 Alaska Native Claims Settlement Act (ANCSA) directed the Secretary of Interior to withdraw up to 32.4 million ha of land for conservation purposes and to prioritize subsistence harvests by Alaska Natives. In response, federal scientists, resource managers, and ENGO conservation advocates identified and then proposed 52.6-million ha for withdrawal from development. This input was from the Bureau of Land Management (BLM), National Park Service (NPS), and U.S. Fish and Wildlife Service (USFWS), along with the ENGOs Audubon Alaska, National Wildlife Federation, Sierra Club, and The Wilderness Society. ANILCA created or expanded many federal conservation units significant to boreal birds, mammals, and fish, including 10 National Wildlife Refuges, seven National Parks or Preserves, and two BLM Conservation or Recreation Areas in the boreal. One of several prominent boreal bird conservation areas set aside was the Yukon Flats National Wildlife Refuge, a remote 3.5-million-ha wetland complex in the northeastern region of Alaska's boreal. Encompassing two globally significant Important Bird Areas for nesting waterfowl (Audubon Alaska 2014), Yukon Flats is managed by the USFWS to conserve fish and wildlife populations and habitats in their natural diversity, including more than 2 million nesting waterfowl and 150 other species of migratory birds (USFWS 2018a). 


\section{Multiple-use public lands}

Approximately $41 \%$ of lands in boreal Alaska are managed for multiple use at the state level by the Alaska Department of Natural Resources (DNR), or at the federal level by the BLM. These agencies must balance multiple uses of these lands, such as ecosystem protection, recreation, economic development (often through resource extraction), and settlement (Hull and Leask 2000), with priority uses varying among planning areas and between agencies. Extensive areas of multiple-use lands remain largely undeveloped and dominate the matrix of lands between protected areas (Fig. 1). Thus, government decisions on how these lands will be used will largely determine regional levels of habitat connectivity for birds and other biota in the future (Magness et al. 2018). Maintaining large-scale connectivity may become increasingly important as species shift their distributional ranges in responses to climate change (Wells et al. 2018).

Multiple-use lands are administered through area or resource management plans (Federal Land Policy and Management Act, AS 38.04.065; Appendix 1) that can classify areas for particular purposes such as Wildlife Habitat Lands (DNR designation), Areas of Critical Environmental Concern, or Riparian Conservation Areas (BLM designations) where conservation of fish and wildlife habitats may be prioritized over other noncompatible uses. For example, the BLM recently prioritized protection of riparian areas, subsistence, and sensitive species over mineral leasing on 895,000 ha of multiple-use lands in eastern interior Alaska (Draanjik and Fortymile Planning Areas). The sensitive species included (among others) Trumpeter Swan (Cygnus buccinator), Bald Eagle (Haliaeetus leucocephalus), and declining Short-eared Owl (Asio flammeus), Olive-sided Flycatcher (Contopus cooperi), Blackpoll Warbler (Setophaga striata), and Rusty Blackbird (Euphagus carolinus; 80 FR 52). Formal comments during the land planning process from ENGOs, state and federal land management and resource agencies, and Alaska Native groups were important in prioritizing these lands for conservation (BLM 2016a,b).

The information required to identify important habitat areas for birds on both multiple-use lands and protected areas is often lacking for boreal birds, particularly for nongame, sensitive, or declining species (ADFG 2015). Avian scientists could therefore assist state and federal land managers by identifying key habitats and concentration areas for these birds more broadly across boreal Alaska (ADFG 2015). For example, land designation decisions can be informed by identification of Important Bird Areas (IBAs; Audubon Alaska 2014), a global network of sites recognized for their significance to bird populations and administered by BirdLife International. In recent years, Audubon Alaska developed geospatial methods for delineating IBAs across Alaska (Smith et al. 2014), and 26 IBAs have been identified for the boreal region, covering 6.7 million ha, or $9 \%$ of the region, with $45 \%$ of the total IBA area within multiple-use and private lands. These IBAs comprise 16 global, 2 continental, and 8 state priority sites, with a total of 33 species qualifying for IBA status at one or more of the three levels. These and other priority sites identified from surveys or spatial modeling and distribution mapping (Amundson et al. 2018) could be used by land managers and the public to (1) nominate new Wildlife Habitat Lands or Areas of Critical Environmental Concern when multiple-use management plans are developed or revised on $\sim 20$ year cycles;
(2) advocate for increasing protection levels for lands within federal protected areas; (3) consider as additions to or during land exchanges between protected areas and adjacent lands; or (4) tailor best management practices to minimize adverse impacts of land use on birds.

\section{Private lands}

Government management agencies and ENGOs also work with Alaska Native Corporations and villages ( $11.7 \%$ of boreal lands), municipalities, and individual private land owners $(2.6 \%$ of boreal lands), by offering conservation grants, technical assistance, or expertise in conservation planning. Programs primarily benefit birds by reducing regional levels of habitat fragmentation from urbanization or promoting sustainable land use practices on private lands (Appendix 1). For example, the Alaska Division of Forestry's Forest Stewardship Program has assisted over 1000 private landowners since 1999 to sustainably manage over 2.9million ha of forests across Alaska for timber, wood energy, fire hazard reduction, or habitat enhancements for game species, such as moose (Alces alces).

\section{Case study: Kenai Mountains to Sea Partnership}

The Kenai Peninsula (Kenai, 4-million ha) is a favorite recreational area as well as a productive region for many species of birds, fish, and other wildlife. Although close to three-quarters of the Kenai is federally managed as conservation lands or for multiple use, the boreal forest lowlands on the western Kenai include 100,000 ha of private land divided into 55,000 parcels. Much of the lowlands remain undeveloped, but may be vulnerable given rapid increases in recent decades in road and home building, highway traffic, recreational fishing pressure, oil and gas development, and tourism (Morton et al. 2015).

The Kenai Mountains to Sea Partnership formed to address habitat fragmentation through strategic conservation of private lands that connect habitats within the federal estate to the coast of Cook Inlet. The partnership is led by the Kachemak Heritage Land Trust and includes Audubon Alaska, Kenai Watershed Forum, Cook Inletkeeper (ENGOs), and the USFWS Kenai National Wildlife Refuge. The overarching goal was to maintain the ecological connectivity along 20 priority river corridors from their headwaters to the sea, including salmon and bird habitats, vegetation, and wildlife crossings. Audubon Alaska worked with academic and federal scientists to build a web-based decisionsupport tool (URL: http://gis.audubon.org/kenai/) to compare and prioritize parcels for acquisition, easement, conservation, restoration, and stewardship. The tool includes IBA boundaries identified by Audubon, species distribution models for species of concern developed by the University of Alaska Anchorage's Alaska Natural Heritage Program, and multitaxa climate change refugia identified by the Kenai National Wildlife Refuge. Users can select among various layers, such as climate refugia, salmon habitat, and IBAs, to identify priority areas for different species or resources. Having a decision-support tool allowed for greater collaboration between groups, which can now discuss their different priorities within the context of a shared framework, evaluate scenarios, and develop a shared vision.

In an additional step to the project, Audubon Alaska worked with the Kachemak Heritage Land Trust to create a bird habitat assessment tool that the land trust can use to evaluate bird values 
on land parcels of interest. Audubon created 179 species distribution models that were aggregated to develop an interactive list of likely bird species by watershed, as well as a list of sitespecific habitat associations for 21 bird species of conservation concern. Land stewards that are not bird experts can use these two products together to identify likely bird species and most valuable habitat at a given site, enabling interparcel comparison and targeted monitoring and restoration. Future efforts to secure habitat connectivity across private lands in other parts of Alaska might similarly benefit from the collaborative and applied approach to science used in this case study.

\section{Managing birds and their habitats}

Most major land use projects in Alaska, including all federal actions, funded projects, and land management plans, require a statement of environmental impacts before they can be permitted to proceed (National Environmental Policy Act [NEPA]; Appendix 1). This review can bring into play a variety of agency regulations to avoid, minimize, or compensate for the adverse environmental impacts of land use activities. Some of the provisions apply directly to birds, nests, and eggs, while others indirectly apply to birds through protections for other ecosystem services or fish and wildlife habitats. In June 2018, the U.S. Council on Environmental Quality (CEQ) announced that it would be developing new implementing regulations for NEPA "to ensure a more efficient, timely, and effective NEPA process" (83 FR 28591). Such changes could substantially revise this bedrock environmental statute, which has remained largely unchanged since 1986 (Malley et al. 2018).

\section{Managing birds, nests, and eggs}

The USFWS oversees the two federal laws that directly protect birds, nests, and eggs from killing, taking, and possession in boreal Alaska: the Migratory Bird Treaty Act (MBTA) and the Bald and Golden Eagle Protection Act (Eagle Act; Appendix 1). The MBTA implements separate conventions on bird conservation with Canada, Mexico, Japan, and Russia and applies to nearly all native bird species, except upland game birds managed by the state. The Eagle Act applies to its namesake species. Both acts prohibit "take," which covers a wide range of actions, i.e., pursue, hunt, shoot, wound, kill, trap, capture, or collect (50 CFR 10.12). In the case of eagles, this also includes "to disturb," which means to agitate to levels that reduce their productivity or survival (50 CRF 22). The Endangered Species Act and its state equivalent (AS 16.20.190; Appendix 1) also protect threatened and endangered species from killing and take, and require special consultation for activities within critical habitats. However, in boreal Alaska there are currently no federal- or state-listed bird species; only marine mammals have federally designated critical habitats (74 FR 51988; USFWS and NMFS 2014, NMFS 2016) that indirectly protect nearshore and shoreline habitats for birds.

The MBTA and Eagle Act were particularly instrumental in recovering bird populations in the first half of the 20th century from overhunting, poaching, and feather collections. For example, Trumpeter Swans had been overharvested for their skin, feathers, or meat to near extinction by the early 1900s. Hunting prohibitions through the MBTA helped recover continental populations (Mitchell and Eichholtz 2010), including a nearly 10fold increase in swan populations from 1968 to 2005 in Alaska (Schmidt et al. 2009). The Eagle Act helped end an Alaska
Territorial bounty on Bald Eagles that killed more than 128,000 birds from 1917 to 1952 (Robards and King 2004). The MBTA remains the foundation for regulating sport harvests of migratory game birds in the U.S. and Canada (50 CFR 20), as well as the spring and early summer subsistence harvests in rural Alaska for migratory birds and eggs traditionally harvested by Alaska Natives (50 CFR 92). Subsistence harvests were not recognized in the MBTA until 1997, and have since been jointly managed by Alaska Natives, the state of Alaska, and the USFWS as equal partners in the Alaska Migratory Bird Co-management Council.

The MBTA and Eagle Act had long been interpreted as strict liability statutes, meaning any unauthorized take is a violation regardless of intent, including activities that unintentionally take birds, many of which would otherwise be legal (incidental take). For example, Exxon violated the MBTA during the 1989 Exxon Valdez oil spill in Prince William Sound, Alaska that killed 250,000 seabirds and 250 Bald Eagles (Bowman et al. 1993, Piatt and Ford 1996). The USFWS has typically managed incidental take by working alongside industries and government organizations (Executive Order 13186) to establish best practices that reduce take, such as bird collisions with structures (APLIC 2012, USFWS 2012, 2016a, b), electrocutions from power lines (APLIC 2006), nest losses during vegetation clearing (USFWS 2017a), toxic exposures to tailing and oil waste ponds (BLM 2012), and seabird bycatch from fisheries (50 CFR 679).

The Eagle Act was strengthened in 2009 through new regulations that authorize the USFWS to issue permits for incidental take of eagle nests and some forms of intentional take of eagle nests (50 CFR 13 and 22). The incidental take permits offer individuals and industries protection from liability when best practices are used to avoid incidental take, but take still occurs. This greater legal clarity provided by incidental take permits is helping the USFWS increase industry use of best practices, such as maintaining buffers (100-800 $\mathrm{m}$ ) between land-use activities and Bald Eagle nesting, foraging, and roosting sites (USFWS 2007). Such best practices have indirectly protected large amounts of coastal and boreal forests in Alaska since the late 1960s (Sampson 2004, Hodges 2011). The new regulations also allow for compensatory mitigation for unavoidable take that reduces eagle populations below regional targets. For example, projects resulting in take of Golden Eagle (Aquila chrysaetos) nests are now contributing funds to help reduce eagle electrocutions from powerlines (APLIC 2006).

Although federal authority to manage incidental take was broadened for the Eagle Act, it is now more limited for the MBTA. On the eve of the 100th anniversary of the MBTA, the Office of the Solicitor for the U.S. Department of Interior (DOI) issued a memorandum entitled "The Migratory Bird Treaty Act does not prohibit incidental take." The memorandum states that the MTBA prohibitions "apply only to affirmative actions that have as their purpose the taking and killing of migratory birds," such as poaching (Solicitor's Opinion M-37050, 22 December 2017). This replaced and reversed the previous Solicitor's Opinion (M-37041, 10 January 2017) that the MBTA strictly prohibits incidental take, which had been the long-standing position held by the Department of Interior for the last half century (Scarlett et al. 2018). The most recent Solicitor's Opinion directs federal implementation of the MBTA unless overturned. Specifically, the 
USFWS will not (1) prosecute or request preventative measures from industries that unintentionally kill birds during their activities, including oil spills (USFWS 2018b), or (2) develop new regulations authorizing incidental take permits through the MBTA, which began in 2015 (80 FR 30032). Federal courts of appeal have been split on whether the MBTA prohibits incidental take, leading some to speculate that the U.S. Supreme Court may eventually review this issue (Graf 2017). In May 2018, several conservation organizations, including National Audubon Society and the American Bird Conservancy filed a lawsuit challenging the most recent Solicitor's Opinion. However, in October 2018, USFWS indicated that it would pursue new implementing regulations defining the scope of the MBTA and thereby codifying the Solicitor's Opinion (Paul 2018).

An important ENGO contribution to the management of boreal bird populations is Audubon Alaska's WatchList, an early warning system for Alaska's birds to identify vulnerable and declining species. The WatchList is developed using criteria to score each regularly occurring species for the percent of global population within the state, overall range size, stewardship responsibility (percent of global habitat within the state), and population trend (Warnock 2017). The Alaska WatchList is regularly consulted by government biologists and others working on management plans and conservation planning for Alaska's bird populations.

\section{Managing bird habitats}

Among the laws protecting fish and wildlife habitats, the most important to the region's birds have been those protecting wetlands. Wetlands are widespread, covering $43 \%$ of boreal Alaska (Hall et al. 1994) and are obligate breeding habitats for several declining boreal bird species (Greenberg et al. 2011, ADFG 2015, Handel and Sauer 2017). Many of boreal Alaska's IBAs are found in wetlands, which can also be essential habitats for salmon and other species with subsistence, commercial, or sport fisheries. Wetlands often include broad conservation constituencies and effective protective regulations (ADFG et al. 2002, Smith and Speed 2013; Appendix 1). Most prominently, wetlands have among the strongest habitat protections through section 404 of the Clean Water Act (Appendix 1). This provision authorizes the U.S. Army Corp of Engineers (USACE) and Environmental Protection Agency to regulate fill placed in wetlands. It requires compensatory mitigation when appropriate and practicable for unavoidable wetlands impacts that are permitted to occur. There are no equivalent protections for upland bird habitats in the U.S. (Angelo and Cotter 2005).

Wetland mitigation is often administered through mitigation banks or in-lieu fee programs (33 CFR 325 and 332, 40 CFR 230) that pool funds to enhance, restore, or preserve wetlands. The Alaska Department of Transportation and Public Facilities alone contributed over $\$ 8$ million to wetlands programs between 2009 and 2015 (Brehmer 2015). USACE has partnered with the Conservation Fund, Great Land Trust, and other ENGOs to use mitigation funds to preserve nearly 19,000 ha of wetlands and adjacent upland habitats across Alaska since 2005 (B. Meikeljohn and D. Mitchell, personal communication) as part of conservation easements, municipal greenbelts, or additions to existing protected areas (Buxton 2011, PBHJV 2015). Mitigation funds are often a nexus for attracting other private donations and grants from federal, state, industry, or ENGO groups, a formula that will likely be increasingly used to conserve key bird habitats in Alaska as land use expands. Because only $36 \%$ of the state's wetlands are mapped in detail, characterizing wetlands across the boreal region will be important for developing a more effective wetland conservation and management strategy in Alaska (ADEC 2015). More detailed wetland maps would also help researchers identify wetlands types that are most important to declining wetland birds (Matsuoka et al. 2010, Lewis et al. 2015).

Although the forest products industry in boreal Alaska has remained small and economically marginal with little impact on the regional forest landscape, future markets and government policies may change and influence harvest levels (Wurtz et al. 2006). As an example, high oil prices during the 2000s spurred interest in wood as an alternative energy (ADC 2016) and included $\$ 1.1$ billion in federal incentives for bioenergy projects in the Food, Conservation, and Energy Act of 2008 (aka 2008 Farm Bill; Stubbs 2010, AFWA 2012). In the mid-2000s the Alaska Division of Forestry received multiple proposals for wood energy projects in the boreal region (ADNR 2007, AEA 2016). Proposals included biomass cogeneration facilities for heat and electricity, which required large, multiyear timber sale contracts to supply the wood. In the end, the large wood biomass projects were not economically feasible after oil prices dropped, and the 2014 Farm Bill repealed bioenergy initiatives for forest biomass and rural energy self-sufficiency (Bracmort 2017).

The Alaska Forest Resources and Practices Act (FRPA; Appendix 1) provides standards for commercial timber operations on state, private, trust, and municipal lands, which make up $45 \%$ of boreal Alaska (Fig. 1). FRPA was established to support timber and commercial fishing industries by protecting riparian habitats and water quality for fish while promoting reforestation after timber harvest. Specific guidance under FRPA for terrestrial wildlife habitat is limited on much of Alaska's public lands and is voluntary on private lands, because wildlife issues are typically addressed through land use planning. However, a recent interagency collaboration has highlighted forestry practices beneficial for both wildlife and reforestation.

\section{Case study: Forestry practices that benefit wildlife and reforestation}

Alaska Department of Fish and Game (ADFG) recently partnered with Alaska Department of Natural Resources (DNR) to review forestry practices that can best sustain wildlife habitat and facilitate reforestation within timber harvest areas. ADFG emphasized how both wildlife diversity and forestry objectives can be simultaneously addressed through retention of late-seral forest habitat in boreal harvest areas (Paragi et al. 2015, 2016). For example, retaining cavity trees provides habitat for birds that prey upon small mammals and insects known to damage seedlings and trees (Fayt et al. 2005, Mooney et al. 2010, Mäntylä et al. 2011). ADFG guidance was reviewed by the Alaska Board of Forestry, endorsed by DNR, and will be put into practice through land use planning and training documents for agency staff and operators. ADFG is currently reviewing landscape-scale harvest practices as a potential means of mimicking natural fire disturbance (Hunter 1993, Delong and Tanner 1996). For example, larger cut blocks that also retain "islands" of late-seral habitat could meet both wildlife population and reforestation 
objectives in boreal forest (Paragi et al. 2015), provided they are proven effective in an adaptive management framework (Walters and Holling 1990, Fisher 2002).

\section{Conservation funding and science}

\section{Funding}

Federal funding is central to conservation and scientific work on birds in boreal Alaska, which often engages multiorganizational collaborations across migratory flyways. Federal dollars come in as grants to the state, Alaska Native groups, and other partners. For example, $\$ 1.1$ billion in federal excise taxes on firearms, ammunition, archery, and sport fishing equipment (Appendix 1) were allocated to state agencies across the U.S. in 2018 to support fish and wildlife conservation. These funds are administered through the USFWS Division of Wildlife and Sport Fish Restoration, and included more than $\$ 50$ million in 2018 to ADFG to fund over 200 fish and wildlife research, management, and restoration projects across Alaska, which benefit game species, including birds (DOI 2018 press release, https://www.doi. gov/pressreleases/secretary-zinke-announces-more-that-11-billionsportsmen-conservation). In contrast, funding for State Wildlife Grants, which support research on declining nongame wildlife species via Alaska's Wildlife Action Plan (ADFG 2015), come through the USFWS via annual appropriation of the U.S. Congress. A recent Blue Ribbon Panel on Sustaining America's Diverse Fish and Wildlife (2016) concluded that an additional $\$ 1.3$ billion in annual federal funding is needed to fully implement existing State Wildlife Action Plans across the U.S., including Alaska (ADFG 2015). The panel also recommended that the required funds could come from existing revenues from energy and mineral resource developments on federal lands and waters.

Other funds for birds are allocated via USFWS competitive grants such as the North American Wetlands Conservation Act and Neotropical Migratory Bird Conservation Act. Both have provided more than $\$ 2$ billion since 1990 toward bird conservation projects by partners throughout international flyways (NAWCC 2016, USFWS 2016c). Similarly, competitive grants through the USFWS Sea Duck Joint Venture (SDVJ Management Board 2014) have supported research on boreal-nesting sea ducks. Agencies also have their own internal funds and competitive grants that support conservation science for birds and other resources. For example, the U.S. Geological Survey (USGS) devotes $\$ 7$ million each year nationally to address the priority science needs of the USFWS and NPS.

ENGOs in Alaska bring in less, but still provide impactful conservation funding from foundations, corporations, and individual donors. ENGO projects are often supported by government funding, such as a State Wildlife Grant (through ADFG) to improve the network of Important Bird Areas across Alaska or USFWS grants to initiate and sustain the Kenai Mountains to Sea Partnership.

\section{Science}

Government and ENGO programs conduct a variety of avian studies aimed at informing bird conservation and management in boreal Alaska. Larger programs in state government include the ADFG Waterfowl Research and Management Program and the Threatened, Endangered, and Diversity Program. The latter program uses State Wildlife Grant funding to focus some of its research effort on nongame "species of greatest conservation need," including declining migratory songbirds, shorebirds, and raptors (ADFG 2015). The work provides scientific guidance to federal agencies regarding listing decisions under the Endangered Species Act, informs management actions, and supports the Alaska Species Ranking System, a tool to direct conservation actions benefitting high priority taxa within the state (Gotthardt et al. 2012, ACCS 2018).

Federal agencies also support several science-based programs that address their information needs about bird populations and habitats. Some scientific programs are specific to agency lands, while others work more broadly across Alaskan landscapes. Agency-specific programs often inventory, monitor, or study birds or other natural resources to assess the capacity of their lands and resource decisions to sustain healthy wildlife populations and habitats into the future. These include the NPS Biological Resources Division and Inventory and Monitoring Division (MacCluskie and Oakley 2005, Hilderbrand et al. 2013) and the USFWS Division of National Wildlife Refuges and Inventory and Monitoring Program (Woodward and Beever 2011, USFWS 2017b).

Programs working more broadly across land jurisdictions include the USFWS Division of Migratory Bird Management, which monitors, studies, and helps conserve and manage populations across flyways, consistent with the MBTA and its international conventions (USFWS 2004). The USGS Alaska Science Center conducts impartial research on federal trust lands and species, e.g., migratory birds, species listed under ESA. This includes long-term monitoring of populations, assessing effects of ecosystem stressors like climate change and oil spills, tracking wildlife diseases, and often uses cutting-edge technologies in animal movements, genetics, and bioinformatics (Holland-Bartels 2007). USGS also supports the Alaska Cooperative Fish and Wildlife Research Unit at the University of Alaska. This partnership between state (university, ADFG) and federal (USGS, USFWS) agencies facilitates university research and graduate student training in support of science-based management of fish, wildlife, and their habitats in Alaska. This Cooperative Research Unit is one of 40 units in the U.S. (USGS 2012).

Two ENGOs focus on conservation of bird populations and habitat within boreal Alaska. Audubon Alaska's work toward boreal bird conservation primarily includes the Alaska WatchList and Important Bird Areas. The Alaska Songbird Institute (https:// aksongbird.org) carries out some of the longest running passerine monitoring program in Alaska, providing data on timing of migration, breeding, and productivity of boreal birds (Irons et al 2017), as well as educational opportunities to the public.

Science-based programs in Alaska often partner together and with others on a diversity of research areas such as avian inventory and monitoring (Handel et al. 2009, Schmidt et al. 2009, Handel and Sauer 2017, Amundson et al. 2018), resource requirements and limiting factors (Corcoran et al. 2007, Edmonds et al. 2010, Lewis et al. 2015, Schmidt et al. 2018), responses to disturbance (Matsuoka et al. 2001, Lewis et al. 2016a, b), migratory connectivity (McIntyre et al. 2008, Johnson et al. 2012, 2017), and adaptations to climate change (Marcot et al. 2015, Roach and Griffith 2015, Mizel et al. 2016, Stralberg et al. 2017). International collaborations have often set conservation priorities and filled key information 
gaps for managing declining species (Greenberg et al. 2011, Booms et al. 2014). An example is the Sea Duck Joint Venture (SDJV), jointly managed by the U.S. and Canada to address declines in multiple populations of North American sea ducks (SDJV Management Board 2014). The SDJV recently sponsored state, provincial, federal, ENGO, and university researchers to conduct satellite telemetry studies on the annual movements of boreal-nesting Barrow's Goldeneye (Bucephala islandica), Surf Scoter (Melanitta perspicillata), and White-winged Scoters ( $M$. fusca). The work identified distinctive subpopulations within the Pacific flyway for monitoring, harvest management, and habitat conservation (Takekawa et al. 2011, Petersen and Savard 2015).

Avian ecologists also importantly contribute data to continental citizen science initiatives such as the Christmas Bird Count, eBird, and North American Breeding Bird Survey (BBS), and have begun analyzing these data with data from Alaska-based programs to better support management and conservation of bird populations. For example, monitoring data from the Alaska Landbird Monitoring Survey (ALMS), were recently analyzed alongside data from the BBS to contrast population trends for birds in roadless (ALMS) versus roadside areas (BBS) of Alaska (Handel and Sauer 2017). Point-count survey data collected by ALMS, BBS, NPS, and a variety of inventory and monitoring surveys across Alaska were compiled with similar data from across the continental boreal by the international collaborative Boreal Avian Modelling Project (BAM; Barker et al. 2015). These data are being analyzed for a wide variety of broad-scale conservation purposes, such as forecasting boreal bird responses to future climate change (Stralberg et al. 2015, 2017) and evaluating the ecological representation of bird habitats by protected areas networks (Lisgo et al. 2017).

Several voluntary multiagency expert groups and governmentENGO partnerships at regional, statewide, or international scales have provided key analyses and initiatives for boreal birds in Alaska. These include bird initiatives that identify conservation priorities for birds such as the Alaska Shorebird Group (ASG 2019), Boreal Partners in Flight (https://www.usgs.gov/centers/ asc/science/boreal-partners-flight), Partners in Flight (Rosenberg et al. 2016), the Pacific Birds Habitat Joint Venture (http://www. pacificbirds.org), and the North American Waterfowl Management Plan (NAWMP 2018). The Northwest Boreal Landscape Conservation Cooperative (NWB LCC 2015) is a unique land and conservation science partnership spanning boreal Alaska and adjacent Canada. Although these initiatives enjoy widespread agency and ENGO participation, many might benefit from increased engagement by avian academics.

\section{Case study: The Northwest Boreal Landscape Conservation Cooperative}

The Northwest Boreal Landscape Conservation Cooperative (NWB LCC) facilitates landscape-scale conservation among more than 30 partners, including federal, state, provincial, and territorial agencies; ENGOs; Tribes (Alaska) and First Nations (Canada); and research institutes. The LCC spans boreal Alaska, Yukon, northern British Columbia, and westernmost Northwest Territories, a region that includes a diversity of boreal forests, alpine environments, and wetlands and rivers over an altitudinal range from sea level to the highest point in North America (NWB LCC 2015). Examples of two conservation projects are detailed below. More information can be found at https://nwblcc.org/.

Connecting protected areas in Alaska: Maintaining landscape connectivity is often a top recommendation for climate adaptation planning (Heller and Zavaleta 2009). Magness et al. (2018) used a land facets approach (Brost and Beier 2012) to identify geophysical features that provide potential connections for species distribution shifts among federal protected areas within and adjacent to a 23.9-million ha multijurisdictional planning area managed by the BLM in Alaska. Geophysical features provide a robust method for climate change planning because they do not change with climate, unlike using current vegetation types to model landscape linkages. Less than $1 \%$ of the planning area could effectively connect 25.9 million ha of federal parks and refuges in the region. Low-elevation areas were particularly important linkages for fish and wildlife passage, and these are expected to include key wetland habitats for waterfowl and other declining bird species (Matsuoka et al. 2010, Lewis et al. 2015). Land managers at BLM and USFWS are now considering the results from these analyses to manage for connectivity among agency lands.

Supporting adaptive management in the face of climate change: The NWB LCC recently collaborated with the Boreal Ecosystems Analysis for Conservation Networks Team (Schmiegelow et al. 2014) to develop an adaptive management framework that identifies ecological benchmarks to help land and resource management agencies across this boreal region conserve largescale ecological processes, sustain fish and wildlife populations, and serve as reference points for monitoring on intact versus actively managed lands (Lisgo et al. 2017). Current reserves as well as lands outside protected areas were evaluated. Ecological benchmarks were also identified and prioritized based on size and intactness, hydrologic connectivity, and how they contribute to regional targets for ecological representation and coverage of focal species habitats. Evaluation included current and projected scenarios under future climate change. Focal species included (among others) late-seral forest birds, such as Boreal Chickadee (Poecile hudsonicus) and Swainson's Thrush (Catharus ustulatus), and wetland birds, such as Trumpeter Swan, declining Lesser Scaup (Aythya affinis), and Rusty Blackbird. This framework seeks to balance biodiversity conservation and sustainable resource use to help multiple stakeholders achieve their goals. The framework can be accessed online as well as information on similar analysis across the boreal at http://www.beaconsproject. $\mathrm{ca} /$.

\section{Future challenges and opportunities}

Addressing the impacts of climate change in boreal Alaska will be particularly challenging. The last half century has already witnessed the following: (1) a regional doubling in the mean area burned to nearly 800,000 ha annually (Kasischke et al. 2010); (2) the largest outbreak of spruce beetles (Dendroctonus rufipennis) recorded in North America, spanning 1.2-million ha of boreal forests in the 1990s (Berg et al. 2006, Werner et al. 2006); (3) a $25 \%$ decrease in boreal lake surface area across National Wildlife Refuges (Riordan et al. 2006, Roach et al. 2013); and (4) a regional decline in boreal forest productivity consistent with a biome shift (Beck et al. 2011). These and other climate-mediated landscape changes are already influencing the distribution, structure, and productivity of boreal bird communities (Corcoran et al. 2007, 
Matsuoka and Handel 2007, Roach and Griffith 2015, Mizel et al. 2016, but see Lewis et al. 2016a, b). The extent and magnitude of such landscape-level changes are expected to increase this century.

At the continental scale, boreal birds are projected to dramatically shift their ranges northward in response to future climate change (Langham et al. 2015, Stralberg et al. 2015). Boreal Alaska is forecast to be continentally prominent in this context by providing (1) habitats for newly colonizing species expanding their ranges from the southern boreal (Stralberg et al. 2017, Wu et al. 2018), as well as (2) future "climate refugia" important for the persistence and adaptive migrations of species that already occur in the region (Stralberg et al. 2018). In terms of range expansions, as many as 40 songbird species are projected to colonize boreal Alaska (Stralberg et al. 2017), and as many as 20 to 40 bird species may colonize individual National Parks in the region by the end of the century ( $\mathrm{Wu}$ et al. 2018). Bird communities as well as agency stewardship responsibilities will dramatically change if new competitors, nest predators (e.g., American Crow, Corvus brachyrhynchos), nest parasites (Brown-headed Cowbird, Molothrus ater), and listed species (e.g., Canada Warbler, Cardellina canadensis; EC 2016) expand into the region, as projected (Stralberg et al. 2017).

Future changes in climate are projected to substantially reduce the potential continental ranges ( $\geq 50 \%$ reduced area) and population sizes $(\geq 20 \%)$ of many species that currently breed in boreal Alaska. Reductions are expected for several wetlandassociated species of conservation concern that are already steeply declining: Horned Grebe (Podiceps auritus), Lesser Scaup, Lesser Yellowlegs (Tringa flavipes), Short-eared Owl, Olive-sided Flycatcher, Bank Swallow (Riparia riparia), Blackpoll Warbler, and Rusty Blackbird (Langham et al. 2015, Stralberg et al. 2015). Identifying and carefully managing habitats for climatevulnerable species will be an important mitigation action to reduce declining ranges and population sizes, particularly for species inhabiting "climate refugia," which are areas expected to be relatively buffered from the effects of continued warming (Morelli et al. 2016). For example, boreal lakes (> 25 ha) are important breeding areas for several declining boreal wetland bird species (Matsuoka et al. 2010, Lewis et al. 2015). Resource managers might prioritize habitat protections around those lakes with features associated with a reduced likelihood of climate-related lake declines (Roach et al. 2011, 2013). Similarly, additional land protections could be considered for current IBAs and other high quality avian habitats with a high potential of retaining stable climates into the future (National Audubon Society 2015). Managing climate refugia as an adaptation strategy may be particularly relevant for Alaska, which among boreal areas was found to have a high potential for climate change macrorefugia (10-km resolution) for North American trees and songbirds. Although coarse-scale features, such as high elevations, valleys, headwaters, and proximity to coasts are associated with macrorefugia (Stralberg et al. 2018), scientists might identify and rank finer scale microrefugia for species to help land managers with climate adaptation planning (Morelli et al. 2016).

\section{CONCLUSIONS}

Alaska has the most extensive network of boreal protected areas, making it the only state or province nearly achieving the goal of protecting half of the land base for boreal birds (Wells et al. 2018). Although the region has a wealth of conservation areas, it also has world-class, untapped natural resources on the remaining unprotected lands, as well as some of the most steeply declining bird species in the continent (Handel and Sauer 2017). There remain significant knowledge gaps on (1) important areas and habitats for many species of conservation concern and (2) the environmental drivers of steep population declines (ADFG 2015). Avian scientists that target these gaps would contribute greatly toward improving the effectiveness of land and species management programs aiming to maintain key bird habitats and reverse negative population trends. More specific knowledge gaps that link directly to on-the-ground management actions and best management practices could be identified and addressed by consulting with relevant agencies and land managers, particularly because management priorities and policies may vary among and even within bureaus over time.

Finally, avian biologists, resource managers, and conservation advocates in Alaska have traditionally targeted specific, conspicuous impacts to birds that resulted from development activities or events, such as the Exxon Valdez oil spill in 1989. In the future, however, Alaskan boreal forests and its birds will face widespread and cumulative impacts not only from increased urban and natural resource developments, but also fundamental changes to ecosystem processes that are already underway as a result of climate change. Addressing the combined impacts of multiple stressors will require scientists to work more closely with land managers and policy makers to detect and anticipate problems, as well as develop science-based solutions that sustain resilient ecosystems and landscapes for boreal bird populations across geopolitical boundaries.

Responses to this article can be read online at: http://www.ace-eco.org/issues/responses.php/1347

\section{Acknowledgments:}

We thank D. Dewhurst, R. Gronquist, D. Hanobic, C. Harwood, L. Heffner, R. Henszey, B. Lance, R. Maroney, D. McBride, J. Muir, L. Philips, T. Rothe, J. Schamber, M. Shephard, J. Speagon, M. Spindler, M. Voleller, and E. Wilt for helping us summarize information about government roles in bird conservation in Alaska. E. Myers, B. Meikeljohn, D. Mitchell, S. Senner, and N. Warnock helped summarize ENGO involvement in boreal conservation in Alaska. We also thank K. Lisgo, D. Magness, B. Matheson, F. Schmiegelow, D. Stralberg, A. Suarez-Esteban, and the rest of the $B E A C O N$ s team for their work presented in the NWB LCC case study. Two anonymous reviewers and E. Cayer, J. Durst, M. Freeman, C. Handel, C. Krenz, J. Pearce, N. Barker, and A. Westwood provided useful comments on improving earlier versions of this manuscript. The findings and conclusions in this article are those of the authors and do not necessarily represent the views of 
the U.S. Fish and Wildlife Service or the Alaska Department of Fish and Game. This publication was facilitated by the Boreal Avian Modelling (BAM) Project, an international research collaboration on the ecology, management, and conservation of boreal birds. We acknowledge BAM's members, avian and biophysical Data Partners, and funding agencies (including Environment and Climate Change Canada and the U.S. Fish and Wildlife Service), listed in full at http://www.borealbirds.calindex.php/acknowledgements.

\section{LITERATURE CITED}

Alaska Center for Conservation Science (ACCS). 2018. Alaska Species Ranking System. ACCS, University of Alaska Anchorage, Anchorage, Alaska, USA.

Alaska Department of Commerce (ADC). 2016. Alaska fuel price report: current community conditions, July 2016. ADC, Community, and Economic Development, Division of Community and Regional Affairs, Research and Analysis Section, Juneau, Alaska, USA.

Alaska Department of Environmental Conservation (ADEC). 2015. Alaska Wetland Program Plan. ADEC, Anchorage, Alaska, USA.

Alaska Department of Fish and Game (ADFG). 2015. Alaska Wildlife Action Plan. ADFG, Juneau, Alaska, USA. [online] URL: http://www.adfg.alaska.gov/index.cfm?adfg=species. wapview

Alaska Department of Fish and Game (ADFG), Alaska Department of Natural Resources, and U.S. Fish and Wildlife Service. 2002. General recommendations for riparian management zones in interior Alaska. U.S. Fish and Wildlife Service, Fairbanks, Alaska, USA. [online] URL: https://www.fws.gov/alaska/ fisheries/fieldoffice/fairbanks/pdf/1_rmzcover.pdf

Alaska Department of Natural Resources (ADNR). 2007. 2007 Annual report. ADNR, Division of Forestry, Juneau, Alaska, USA.

Alaska Department of Natural Resources (ADNR). 2018. Alaska DNR surface classification: general land, October 2018. ADNR, Information Resource Management, Anchorage, Alaska, USA.

Alaska Energy Authority (AEA). 2016. Renewable energy atlas of Alaska: a guide to Alaska's clean, local, and inexhaustible energy resources. AEA, Anchorage, Alaska, USA. [online] URL: http:// www.akenergyauthority.org/Portals/0/Publications/2015HighRes. pdf?ver=2016-04-21-120237-447

Alaska Shorebird Group (ASG). 2019. Alaska Shorebird Conservation Plan, version III. Alaska Shorebird Group, Anchorage, Alaska, USA.

Amundson, C. L., C. M. Handel, D. R. Ruthrauff, T. L. Tibbitts, and R. E. Gill, Jr. 2018. Montane-breeding bird distribution and abundance across National Parks of southwestern Alaska. Journal of Fish and Wildlife Management 9(1):180-207. http://dx. doi.org/10.3996/062017-JFWM-050

Angelo, M. J., and A. J. Cotter. 2005. Redressing the failure of environmental law to protect birds and their habitat. Natural Resources and Environment 25:22-27.
Association of Fish and Wildlife Agencies (AFWA). 2012. Assessment of the bioenergy provisions in the 2008 Farm Bill. AFWA, Washington, D.C., USA.

Audubon Alaska. 2014. Important Bird Areas of Alaska, version 3. Audubon Alaska, Anchorage, Alaska, USA. [online] URL: http://databasin.org/datasets/f9e442345fb54ae28cf72f249d2c23a9

Avian Power Line Interaction Committee (APLIC). 2006. Suggested practices for avian protection on powerlines: the state of the art in 2006. Edison Electric Institute, APLIC, and the California Energy Commission, Washington, D.C., and Sacramento, California, USA.

Avian Power Line Interaction Committee (APLIC). 2012. Reducing avian collisions with power lines: the state of the art in 2012. Edison Electric Institute and APLIC, Washington, D.C., USA.

Barker, N. K. S., P. C. Fontaine, S. G. Cumming, D. Stralberg, A. Westwood, E. M. Bayne, P. Sólymos, F. K. A. Schmiegelow, S. J. Song, and D. J. Rugg. 2015. Ecological monitoring through harmonizing existing data: lessons from the Boreal Avian Modelling Project. Wildlife Society Bulletin 39:480-487. http://dx. doi.org/10.1002/wsb.567

Beck, P. S. A., G. P. Juday, C. Alix, V. A. Barber, S. E. Winslow, E. E. Sousa, P. Heiser, J. D. Herriges, and S. J. Goetz. 2011 Changes in forest productivity across Alaska consistent with biome shift. Ecological Letters 14:373-379. http://dx.doi. org/10.1111/j.1461-0248.2011.01598.x

Berg, E. E., J. D. Henry, C. L. Fastie, A. D. De Volder, and S. M Matsuoka. 2006. Spruce beetle outbreaks on the Kenai Peninsula, Alaska and Kluane National Park and Reserve, Yukon Territory: relationship to summer temperatures and regional differences in disturbance regimes. Forest Ecology and Management 227:219-232. http://dx.doi.org/10.1016/j.foreco.2006.02.038

Blancher, P., and J. Wells. 2005. The boreal forest region: North America's bird nursery. Canadian Boreal Initiative, Ottawa, Ontario, Canada and Boreal Songbird Initiative, Seattle, Washington, USA.

Blue Ribbon Panel on Sustaining America's Diverse Fish and Wildlife. 2016. The future of America's fish and wildlife: a 21st century vision for investing in and connecting people to nature. Association of Fish and Wildlife Agencies, Washington, D.C., USA.

Booms, T. L., G. L. Holroyd, M. A. Gahbauer, H. E. Trefry, D. A. Wiggins, D. W. Holt, J. A. Johnson, S. B. Lewis, M. D. Larson, K. L. Keyes, and S. Swengel. 2014. Assessing the status and conservation priorities of the Short-eared Owl in North America. Journal of Wildlife Management 78:772-778. http://dx.doi. org/10.1002/jwmg.719

Bowman, T. D., P F. Schempf, and J. A. Bernatowicz. 1993. Effects of the Exxon Valdez oil spill on Bald Eagles. Exxon Valdez Oil Spill State/Federal Natural Resources damage assessment final report, bird study Number 4. U.S. Fish and Wildlife Service, Anchorage, Alaska, USA.

Bracmort, K. 2017. Energy provisions in the 2014 Farm Bill (P. L. 113-79): status and funding. Congressional Research Service Report R43416. 
Brandt, J. P. 2009. The extent of the North American boreal zone. Environmental Reviews 17:101-161. http://dx.doi.org/10.1139/ A09-004

Brehmer, E. 2015. State shifts to 404 primacy to wetlands mitigation options. Alaska Journal of Commerce January (3).

Brost, B. M., and P. Beier. 2012. Use of land facets to design linkages for climate change. Ecological Applications 22:87-103. http://dx.doi.org/10.1890/11-0213.1

Bureau of Land Management (BLM). 2012. Fluid minerals operations: reducing preventable causes of direct wildlife mortality. Instructional Memorandum 2013-033, BLM, Washington, D.C., USA.

Bureau of Land Management (BLM). 2016a. Draanjik: record of decision and approved resource management plan. U.S. Department of Interior, BLM, Alaska, Eastern Interior Field Office, Fairbanks, Alaska, USA.

Bureau of Land Management (BLM). 2016b. Fortymile: record of decision and approved resource management plan. U.S. Department of Interior, BLM, Alaska, Eastern Interior Field Office, Fairbanks, Alaska, USA.

Buxton, M. 2011. Fairbanks land trust shielding sensitive areas from development. Fairbanks Daily News-Miner, 4 September. [online] URL: http://www.newsminer.com/fairbanks-land-trustshielding-sensitive-areas-from-development/article_04233520-2602-526dbaeb-9ec233074e25.html

Canadian Council on Ecological Areas (CCEA). 2017. Conservation Areas Reporting and Tracking System: report on protected areas in Canada. CCEA. [online] URL: https://ccea.org/ wp-content/uploads/2019/04/CARTS2017ReportEN.pdf

Chapin, F. S., III, M. W. Oswood, K. Van Cleve, L. A. Viereck, and D. L. Verbyla, editors. 2006. Alaska's changing boreal forest. Oxford University Press, New York, New York, USA.

Committee on the Status of Endangered Wildlife in Canada (COSEWIC). 2008. COSEWIC assessment and update status report on the Short-eared Owl Asio flammeus in Canada. COSEWIC, Ottawa, Ontario, Canada.

Committee on the Status of Endangered Wildlife in Canada (COSEWIC). 2009. COSEWIC assessment and status report on the Horned Grebe Podiceps auritus in Canada. COSEWIC, Ottawa, Ontario, Canada.

Committee on the Status of Endangered Wildlife in Canada (COSEWIC). 2013. COSEWIC assessment and status report on the Bank Swallow Riparia riparia in Canada. COSEWIC, Ottawa, Ontario, Canada.

Committee on the Status of Endangered Wildlife in Canada (COSEWIC). 2014. COSEWIC assessment and status report on the Red-necked Phalarope Phalaropus lobatus in Canada. COSEWIC, Ottawa, Ontario, Canada.

Committee on the Status of Endangered Wildlife in Canada (COSEWIC). 2018. COSEWIC assessment and status report on the Rusty Blackbird Euphagus carolinus in Canada. COSEWIC, Ottawa, Ontario, Canada.
Corcoran, R. M., J. R. Lovvorn, M. R. Bertram, and M. T. Vivion. 2007. Lesser Scaup nest success and duckling survival on the Yukon Flats, Alaska. Journal of Wildlife Management 71:127-134. http://dx.doi.org/10.2193/2005-534.

Delong, S. C., and D. Tanner. 1996. Managing the pattern of forest harvest: lessons from wildfire. Biodiversity and Conservation 5:1191-1205. http://dx.doi.org/10.1007/BF00051571

Edmonds, S. T., D. C. Evers, D. A. Cristol, C. Mettke-Hofmann, L. L. Powell, A. J. McGann, J. W. Armiger, O. P. Lane, D. F. Tessler, P. Newell, K. Heyden, and N. J. O'Driscoll. 2010. Geographic and seasonal variation in mercury exposure of the declining Rusty Blackbird. Condor 112:789-799. http://dx.doi.org/10.1525/ cond.2010.100145

Environment Canada (EC). 2015a. Management plan for the Rusty Blackbird (Euphagus carolinus) in Canada. Species at Risk Act Management Plan Series. EC, Ottawa, Ontario, Canada.

Environment Canada (EC). 2015b. Recovery strategy for Olivesided Flycatcher (Contopus cooperi) in Canada [Proposed]. Species at Risk Act Recovery Strategy Series. EC, Ottawa, Ontario, Canada.

Environment Canada (EC). 2016. Recovery strategy for the Canada Warbler (Cardellina canadensis) in Canada. Species at Risk Act Recovery Strategy Series. EC, Ottawa, Canada.

Environment and Climate Change Canada (ECCC). 2017. North American Breeding Bird Survey: Canadian trends website, dataversion 2015. ECCC, Gatineau, Québec, Canada.

Fayt, P., M. M. Machmer, and C. Steeger. 2005. Regulation of spruce bark beetles by woodpeckers: a literature review. Forest Ecology and Management 206:1-14. http://dx.doi.org/10.1016/j. foreco.2004.10.054

Fisher, J. T. 2002. Adaptive boreal forestry: anticipation and experimentation. Pages 12-1 to 12-15 in S. J. Song, editor. Ecological basis for stand management: a synthesis of ecological responses to wildfire and harvesting. Alberta Research Council Inc., Vegreville, Alberta, Canada.

Gotthardt, T. A., K. M. Walton, and T. L. Fields. 2012. Setting priorities for Alaska's species of greatest conservation need: the Alaska Species Ranking System (ASRS). Alaska Natural Heritage Program, University of Alaska Anchorage, Anchorage, Alaska, USA.

Graf, J. P. 2017. Take two: the Fifth Circuit's interpretation of the Migratory Bird Treaty Act in Untied States v. CITGO. LSU Journal of Energy, Law, and Resources 5:184-208.

Greenberg, R., D. W. Demarest, S. M. Matsuoka, C. MettkeHofmann, M. L. Avery, P. J. Blancher, D. Evers, P. B. Hamel, K. A. Hobson, J. Luscier, D. K. Niven, L. L. Powell, and D. Shaw. 2011. Understanding declines in Rusty Blackbirds. Pages 107-125 in J. V. Wells, editor. Boreal birds of North America: a hemispheric view of their conservation links and significance. Studies in Avian Biology (no. 41), University of California Press, Berkeley, California, USA.

Hall, J. V., W. E. Frayer, and B. O. Wilen. 1994. Status of Alaska wetlands. U.S. Fish and Wildlife Service, Alaska Region, Anchorage, Alaska, USA. 
Handel, C. M., and J. R. Sauer. 2017. Combined analysis of roadside and off-road breeding bird survey data to assess population change in Alaska. Condor 119:557-575. http://dx.doi. org/10.1650/CONDOR-17-67.1

Handel, C. M., S. A. Swanson, D. A. Nigro, and S. M. Matsuoka. 2009. Estimation of avian population sizes and species richness across a boreal landscape in Alaska. Wilson Journal of Ornithology 121:528-547. http://dx.doi.org/10.1676/08-067.1

Heller, N. E., and E. S. Zavaleta. 2009. Biodiversity management in the face of climate change: a review of 22 years of recommendations. Biological Conservation 142:14-32. http://dx. doi.org/10.1016/j.biocon.2008.10.006

Hilderbrand, G., K. Joly, S. Rabinowitch, and B. Schults. 2013. Wildlife stewardship in National Park Service areas in Alaska. Natural Resource Report NPS/AKSO/NRR-2013/663. Department of the Interior, National Park Service, Fort Collins, Colorado, USA.

Hodges, J. I. 2011. Bald Eagle population surveys of the North Pacific Ocean, 1967-2010. Northwestern Naturalist 92:7-12. http:// dx.doi.org/10.1898/10-03.1

Holland-Bartels, L. E. 2007. Alaska Science Center. U.S. Geological Survey Fact Sheet 2007-3019. U.S. Geological Survey, Alaska Science Center, Anchorage, Alaska, USA.

Hull, T., and L. Leask. 2000. Dividing Alaska, 1867-2000: changing land ownership and management. Alaska Review of Social and Economic Conditions 32(1):1-14.

Hunter, M. L., Jr. 1993. Natural fire regimes as spatial models for managing boreal forests. Biological Conservation 65:115-120. http://dx.doi.org/10.1016/0006-3207(93)90440-C

Intergovernmental Panel on Climate Change (IPCC). 2014. Climate Change 2014: synthesis report. Contribution of Working Groups I, II and III to the Fifth Assessment Report of the Intergovernmental Panel on Climate Change. Core Writing Team, R. K. Pachauri, and L. A. Meyer, editors. IPCC, Geneva, Switzerland.

Irons, R. D., A. Harding Scurr, A. P. Rose, J. C. Hagelin, T. Blake, and D. F. Doak. 2017. Wind and rain are the primary climate factors driving changing phenology of an aerial insectivore. Proceedings of the Royal Society, Series B 284:20170412. http:// dx.doi.org/10.1098/rspb.2017.0412

Johnson, J. A., T. L. Booms, L. H. DeCicco, and D. C. Douglas. 2017. Seasonal movements of the Short-eared Owl (Asio flammeus) in western North America as revealed by satellite telemetry. Journal of Raptor Research 51:115-128. http://dx.doi. org/10.3356/JRR-15-81.1

Johnson, J. A., S. M. Matsuoka, D. F. Tessler, R. Greenberg, and J. W. Fox. 2012. Identifying migratory pathways used by Rusty Blackbirds breeding in southcentral Alaska. Wilson Journal of Ornithology 124:698-703. http://dx.doi.org/10.1676/1559-4491-124.4.698

Karl, S. M., J. V. Jones, III, and T. S. Hayes, editors. 2016. GISbased identification of areas that have resource potential for critical minerals in six selected groups of deposit types in Alaska. USGS Open-File Report 2016-1191. U.S. Geological Survey, Reston, Virginia, USA. http://dx.doi.org/10.3133/ofr20161191
Kasischke, E. S., D. L. Verbyla, T. S. Rupp, A. D. McGuire, K. A. Murphy, R. Jandt, J. L. Barnes, E. E. Hoy, P. A. Duffy, M. Calef, and M. R. Turetsky. 2010. Alaska's changing fire regime: implications for the vulnerability of its boreal forests. Canadian Journal of Forest Research 40:1313-1324. http://dx.doi. org/10.1139/X10-098

Langham, G. M., J. G. Schuetz, T. Distler, C. U. Soykan, and C. Wilsey. 2015. Conservation status of North American birds in the face of future climate change. PLoS ONE 10(9):e0135350. http:// dx.doi.org/10.1371/journal.pone.0135350

Lewis, T. L., P. J. Heglund, M. S. Lindberg, J. A. Schmutz, J. H. Schmidt, A. J. Dubour, J. Rover, and M. R. Bertram. $2016 b$. Trophic dynamics of shrinking Subarctic lakes: naturally eutrophic waters impart resilience to rising nutrient and major ion concentrations. Oecologia 181:583-596. http://dx.doi. org/10.1007/s00442-016-3572-y

Lewis, T. L., M. S. Lindberg, J. A. Schmutz, M. R. Bertram, and A. J. Dubour. 2015. Species richness and distributions of boreal waterbird broods in relation to nesting and brood-rearing habitats. Journal of Wildlife Management 79:296-310. http://dx. doi.org/10.1002/jwmg.837

Lewis, T. L., J. A. Schmutz, C. L. Amundson, and M. S. Lindberg. 2016a. Waterfowl populations are resilient to immediate and lagged impacts of wildfires in the boreal forest. Journal of Applied Ecology 53:1746-1754. http://dx.doi.org/10.1111/1365-2664.12705

Lisgo, K., F. Schmiegelow, P. Vernier, M. Edwards, and A. SuárezEsteban. 2017. Ecological benchmarks to support landscape conservation design in the Northwest Boreal LCC planning region. BEACONs Project, University of Alberta, and Yukon College, Whitehorse, Yukon, Canada. [online] URL: http://www. beaconsproject.ca/nwb

MacCluskie, M., and K. Oakley. 2005. Central Alaska Network: vital signs monitoring plan. National Park Service, Fairbanks, Alaska, USA.

Magness, D. R., A. L. Sesser, and T. Hammond. 2018. Using topographic geodiversity to connect conservation lands in the Central Yukon, Alaska. Landscape Ecology 33:547-556. http://dx. doi.org/10.1007/s10980-018-0617-0

Malley, W. G., L. G. Zagar, and J. E. Aronson. 2018. CEQ invites comments on potentially sweeping changes to NEPA regulations. News \& Insights: Perkins Coie, 21 June. [online] URL: https:// www.perkinscoie.com/en/news-insights/ceq-invites-comments-onpotentially-sweeping-changes-to-nepa.html

Mäntylä, E., T. Klemola, and T. Laaksonen. 2011. Birds help plants: a meta-analysis of top-down trophic cascades caused by avian predators. Oecologia 165:143-151. http://dx.doi.org/10.1007/ s00442-010-1774-2

Marcot, B. G., M. T. Jorgenson, J. P. Lawler, C. M. Handel, and A. R. DeGange. 2015. Projected changes in wildlife habitats in Arctic natural areas of northwest Alaska. Climate Change 130:145-154. http://dx.doi.org/10.1007/s10584-015-1354-x

Matsuoka, S. M., and C. M. Handel. 2007. Nesting ecology of boreal forest birds following a massive outbreak of spruce beetles. Journal of Wildlife Management 71:51-63. http://dx.doi. org/10.2193/2005-460 
Matsuoka, S. M., C. M. Handel, and D. R. Ruthrauff. 2001. Densities of breeding birds and changes in vegetation in an Alaska boreal forest following a massive disturbance by spruce beetles. Canadian Journal of Zoology 79:1678-1690. http://dx.doi. org/10.1139/z01-130

Matsuoka, S. M., D. Shaw, and J. A. Johnson. 2010. Estimating the abundance of nesting Rusty Blackbirds in relation to wetland habitats in Alaska. Condor 112:825-833. http://dx.doi. org/10.1525/cond.2010.100148

McIntyre, C. L., D. C. Douglas, and M. W. Collopy. 2008. Movements of Golden Eagles (Aquila chrysaetos) from interior Alaska during their first year of independence. Auk 125:214-224. http://dx.doi.org/10.1525/auk.2008.125.1.214

Mitchell, C. D., and M. W. Eichholz. 2010. Trumpeter Swan (Cygnus buccinator), version 2.0. In A. F. Poole, editor. Birds of North America. American Ornithological Society and Cornell Lab of Ornithology, Ithaca, New York, USA. https://doi. org/10.2173/bna.105

Mizel, J. D., J. H. Schmidt, C. L. McIntyre, and C. A. Roland. 2016. Rapidly shifting elevational distributions of passerine species parallel vegetation change in the subarctic. Ecosphere 7 (3):e01264. http://dx.doi.org/10.1002/ecs2.1264

Mooney, K. A., D. S. Gruner, N. A. Barber, S. A. Van Bael, S. M. Philpott, and R. Greenberg. 2010. Interactions among predators and the cascading effects of vertebrate insectivores on arthropod communities and plants. Proceedings of National Academy of Sciences 107:7335-7340. http://dx.doi.org/10.1073/pnas.1001934107

Morelli, T. L., C. Daly, S. Z. Dobrowski, D. M. Dulen, J. L. Ebersole, S. T. Jackson, J. D. Lundquist, C. I. Millar, S. P. Maher, W. B. Monahan, K. R. Nydick, K. T. Redmond, S. C. Sawyer, S. Stock, and S. R. Beissinger. 2016. Managing climate change refugia for climate adaptation. PLoS ONE 11(8):e0159909. https://doi.org/10.1371/journal.pone.0159909

Morton, J. M., D. R. Magness, M. McCarty, D. Wigglesworth, R. Ruffner, M. Bernard, N. Walker, H. Fuller, S. Mauger, B. Bornemann, L. Fuller, M. Smith, and A. Borass. 2015. Kenai Mountains to Sea: a land conservation strategy to sustain our way of life on the Kenai Peninsula. Kachemak Heritage Land Trust, Audubon Alaska, Cook Inletkeeper, Kenai Watershed Forum, U. S. Fish and Wildlife Service, Kenai, Alaska, USA.

National Audubon Society. 2015. Audubon's birds and climate change report: a primer for practitioners. National Audubon Society, New York, New York, USA.

National Gap Analysis Program. 2016. Protected areas database of the United States, version 1.4, combined feature class. U.S. Geological Survey, Boise, Idaho, USA.

National Marine Fisheries Service (NMFS). 2016. Recovery plan for the Cook Inlet beluga whale (Delphinapterus leucas). NMFS, Alaska Region, Protected Resources Division, Juneau, Alaska, USA.

North American Waterfowl Management Plan (NAWMP). 2018. 2018 North American Waterfowl Management Plan (NAWMP) update: connecting people, waterfowl, and wetlands. NAWMP, U. $\mathrm{S}$. Department of the Interior, Environment and Climate Change
Canada, and Environment and Natural Resources Mexico. [online] URL: https://nawmp.org/sites/default/files/2018-12/6056\% 202018\%20NAWMP\%20Update_EN16.pdf

North American Wetlands Conservation Council (NAWCC). 2016. North American Wetlands Conservation Act, 2014-2015 progress report. NAWCC, Leesburg Pike, Mississippi, USA.

Northwest Boreal Landscape Conservation Cooperative (NWB LCC). 2015. Strategic plan 2015-2025, version 1.0. Northwest Boreal Landscape Conservation Cooperative, Anchorage, Alaska, USA. [online]. URL: http://nwblcc.org/wp-content/ uploads/2015/05/NWB-LCC-Strategic-Plan-V1.pdf

Pacific Birds Habitat Joint Venture (PBHJV). 2015. Alaska land trusts: 40,000 acres and going strong. PBHJV Partner News and Resources, 27 July. [online] URL: https://pacificbirds.org/2015/07/ alaska-land-trusts-25-years-and-going-strong/

Paragi, T., J. Hagelin, and S. Brainerd. 2015. Habitat guidelines for boreal forest management. Alaskan Wildlifer, Fall Issue:9-10. [online] URL: http://wildlife.org/wp-content/uploads/2015/12/ TWS_AK_Newsletter_Fall_2015.pdf

Paragi, T. F., J. C. Hagelin, and S. M. Brainerd. 2016. Wildlifereforestation interactions and adaptive management. Pages 122-186 in M. Freeman and J. Durst, editors. Forest resources and practices, Region II-III reforestation review, annotated bibliography. Alaska Department of Natural Resources, Division of Forestry, Anchorage, Alaska, USA and Alaska Department of Fish and Game, Habitat Division, Fairbanks, Alaska, USA. [online] URL: http://forestry.alaska.gov/Assets/pdfs/forestpractices/ S\&TC\%20Annotated \%20Bibliography\%20August-30-2016.doc

Paul, E. 2018. MBTA incidental take situation worsens; formal regulations to be proposed. Ornithology Exchange, 17 October. [online] URL: http://ornithologyexchange.org/articles/community/ mbta-incidental-take-situation-worsens-formal-regulation-to-beproposed-r267

Petersen, M. R., and J.-P. L. Savard. 2015. Variation in migration strategies of North American sea ducks. Pages 267-304 in J.-P. L. Savard, D. V. Derksen, D. Esler, and J. M. Eadie, editors. Ecology and conservation of North American sea ducks. Studies in Avian Biology (no. 46), University of California Press, Berkeley, California, USA.

Piatt, J. F., and R. G. Ford. 1996. How many seabirds were killed by the Exxon Valdez oil spill? American Fisheries Society Symposium 18:712-719.

Riordan, B., D. Verbyla, and A. D. McGuire. 2006. Shrinking ponds in subarctic Alaska based on 1950-2002 remotely sensed images. Journal of Geophysical Research 111:G04002. http://dx. doi.org/10.1029/2005JG000150

Roach, J., B. Griffith, D. Verbyla, and J. Jones. 2011. Mechanisms influencing changes in lake area in Alaskan boreal forest. Global Change Biology 17:2567-2583. http://dx.doi.org/10.1111/ j.1365-2486.2011.02446.x

Roach, J. K., and B. Griffith. 2015. Climate-induced lake drying causes heterogeneous reductions in waterfowl species richness. Landscape Ecology 30:1005-1022. http://dx.doi.org/10.1007/ s10980-015-0207-3 
Roach, J. K., B. Griffith, and D. Verbyla. 2013. Landscape influences on climate-related lake shrinkage at high latitudes. Global Change Biology 19:2276-2284. http://dx.doi.org/10.1111/ gcb. 12196

Robards, F. C., and J. G. King. 2004. Nesting and productivity of Bald Eagles in southeast Alaska, 1966. Pages 105-110 in B. A Wright and P. F. Schempf, editors. Bald Eagles in Alaska. Bald Eagle Research Institute, University of Alaska Southeast, Juneau, Alaska, USA.

Robinson, D., E. Hunsinger, E. Snadberg, and L. Brooks. 2017. Alaska population overview: 2016 estimates. Alaska Department of Labor and Workforce Development, Research and Analysis Section, Juneau, Alaska, USA.

Rosenberg, K. V., J. A. Kennedy, R. Dettmers, R. P. Ford, D. Reynolds, J. D. Alexander, C. J. Beardmore, P. J. Blancher, R. E. Bogart, G. S. Butcher, A. F. Camfield, A. Couturier, D. W. Demarest, W. E. Easton, J. J. Giocomo, R. H. Keller, A. E. Mini, A. O. Panjabi, D. N. Pashley, T. D. Rich, J. M. Ruth, H. Stabins, J. Stanton, and T. Will. 2016. Partners in Flight Landbird Conservation Plan: 2016 revision for Canada and continental United States. Partners in Flight Science Committee.

Sampson, F. B. 2004. Cooperative management of the Bald Eagle in south coastal Alaska. Pages 281-287 in B. A Wright and P. F. Schempf, editors. Bald Eagles in Alaska. Bald Eagle Research Institute, University of Alaska Southeast, Juneau, Alaska, USA.

Sauer, J. R., D. K. Niven, K. L. Pardiek, D. J. Ziolkowski, Jr., and W. A. Link. 2017. Expanding the North American Breeding Bird Survey analysis to include additional species and regions. Journal of Fish and Wildlife Management 8:154-172. http://dx.doi. org/10.3996/102015-JFWM-109

Scarlett, L., D. J. Hayes, N. Reed, D. Barry, L. Laverty, L. Greenwalt, J. Turner, J. Rappaport Clark, S. Williams, D. M. Ashe, J. Rogers, R. Sparrowe, T. Dwyer, P. Schmidt, J. Andrew, R. Blohm, and B. Bortner. 2018. Letter from 17 former Interior officials to Secretary Ryan Zinke on new Migratory Bird Treaty Act Policy. Washington Post, 10 January. [online] URL: http:// apps.washingtonpost.com/g/documents/national/letter-from-17-formerinterior-officials-to-secretary-ryan-zinke-on-new-migratory-birdtreaty-act-policy/2708

Schmidt, J. H., M. S. Lindberg, D. S. Johnson, B. Conant, and J. King. 2009. Evidence of Alaskan Trumpeter Swan population growth using Bayesian hierarchical models. Journal of Wildlife Management 73:270-727. http://dx.doi.org/10.2193/2008-262

Schmidt, J. H., C. L. McIntyre, C. A. Roland, M. C. MacCluskie, and M. J. Flamme. 2018. Bottom-up processes drive reproductive success in an apex predator. Ecology and Evolution 8 (3):1833-1841. https://doi.org/10.1002/ece3.3800

Schmiegelow, F. K. A., S. G. Cumming, K. A. Lisgo, S. J. Leroux, and M. A. Krawchuk. 2014. Catalyzing large landscape conservation in Canada's boreal systems: the BEACONs Project experience. Pages 97-122 in J. N. Levitt, editor. Conservation catalysts. Lincoln Institute of Land Policy, Cambridge, Massachusetts, USA.

Sea Duck Joint Venture (SDJV) Management Board. 2014. Sea Duck Joint Venture strategic plan 2014-2018. U.S. Fish and
Wildlife Service, Anchorage, Alaska, USA and Canadian Wildlife Service, Sackville, New Brunswick, Canada.

Smith, C., and J. Speed, editors. 2013. Conserving salmon habitat in the Mat-Su Basin: the strategic action plan of the Mat-Su Basin Salmon Habitat Partnership, 2013 update. The Nature Conservancy, Anchorage, Alaska, USA.

Smith, M. A., N. J. Walker, C. M. Free, M. J. Kirchhoff, G. S. Drew, N. Warnock, and I. J. Stenhouse. 2014. Identifying marine Important Bird Areas using at-sea survey data. Biological Conservation 172:180-189. http://dx.doi.org/10.1016/j.biocon.2014.02.039

Stralberg, D., C. Carroll, J. H. Pedlar, C. B. Wilsey, D. W. McKenney, and S. E. Nielsen. 2018. Macrorefugia for North American trees and songbirds: climatic limiting factors and multiscale topographic influences. Global Ecology and Biogeography 27:690-703. http://dx.doi.org/10.1111/geb.12731

Stralberg, D., S. M. Matsuoka, A. Hamann, E. M. Bayne, P. Sólymos, F. K. A. Schmiegelow, X. Wang, S. G. Cumming, and S. J. Song. 2015. Projecting boreal bird responses to climate change: the signal exceeds the noise. Ecological Applications 25:52-69. http://dx.doi.org/10.1890/13-2289.1

Stralberg, D., S. M. Matsuoka, C. M. Handel, F. K. A. Schmiegelow, A. Hamman, and E. M. Bayne. 2017. Biogeography of boreal passerine range dynamics in western North America: past, present, and future. Ecography 40:1050-1066. http://dx.doi. org/10.1111/ecog.02393

Stubbs, M. 2010. Renewable energy programs in the 2008 Farm Bill. Congressional Research Service Reports for Congress RL34130.

Takekawa, J. Y., S. W. De La Cruz, M. T. Wilson, E. C. Palm, J. Lee, D. R. Nysewander, J. R. Evenson, D. Esler, W. S. Boyd, and D. H. Ward. 2011. Breeding synchrony, sympatry, and nesting areas of Pacific Coast Surf Scoters (Melanitta perspicillata). Pages 41-64 in J. V. Wells, editor. Boreal birds of North America: a hemispheric view of their conservation links and significance. Studies in Avian Biology (no. 41). University of California Press, Berkeley, California, USA.

Todderud, E. 1987. The Alaska Lands Act: a delicate balance between conservation and development. Public Land Resources Law Review 8:143-163.

U.S. Army Corp of Engineers (USACE). 2018. Donlin Gold Project: final Environmental Impact Statement. U.S. Army Corp of Engineers, CEPOA-RD, Joint Base Elmendorf-Richardson, Alaska, USA.

U.S. Army Corp of Engineers (USACE). 2019. Pebble Project EIS: draft environmental impact statement. USACE, Joint Base Elmendorf-Richardson, Alaska, USA.

U.S. Fish and Wildlife Service (USFWS). 2004. A blueprint for the future of migratory birds: Migratory Bird Program Strategic Plan 2004-2014. USFWS, Migratory Birds and State Programs, Arlington, Virginia, USA.

U.S. Fish and Wildlife Service (USFWS). 2007. National Bald Eagle management guidelines. USFWS, Migratory Bird Management, Arlington, Virginia, USA. 
U.S. Fish and Wildlife Service (USFWS). 2008. Revised Comprehensive Conservation Plan: Kanuti National Wildlife Refuge. USFWS, Kanuti National Wildlife Refuge, Fairbanks, Alaska, USA and Division of Conservation Planning and Policy, Anchorage, Alaska, USA.

U.S. Fish and Wildlife Service (USFWS). 2012. U.S. Fish and Wildlife Service land-based wind energy guidelines. USFWS, Arlington, Virginia, USA.

U.S. Fish and Wildlife Service (USFWS). 2015. Arctic National Wildlife Refuge: revised Comprehensive Conservation Plan, final Environmental Impact Statement, Wilderness review, Wild and Scenic River review. Volumes 1-4. USFWS, Arctic National Wildlife Refuge, Fairbanks, Alaska, USA and Division of Conservation Planning and Policy, Anchorage, Alaska, USA.

U.S. Fish and Wildlife Service (USFWS). 2016a. Recommended best practices for communication tower design, siting, construction, operation, maintenance, and decommissioning. USFWS, Division of Migratory Bird Management, Falls Church, Virginia, USA.

U.S. Fish and Wildlife Service (USFWS). 2016b. Reducing bird collisions with buildings and building glass: best practices. USFWS, Division of Migratory Bird Management, Falls Church, Virginia, USA.

U.S. Fish and Wildlife Service (USFWS). 2016c. Leveraging funds for effective conservation in the Americas: Neotropical Migratory Bird Conservation Act. USFWS, Division of Habitat Conservation, Falls Church, Virginia, USA. [online] URL: https://www.fws.gov/migratorybirds/pdf/grants/neotrop-overview. pdf

U.S. Fish and Wildlife Service (USFWS). 2017a. Timing recommendations for land disturbance and vegetation clearing: planning ahead to protect nesting birds. USFWS, Division of Fisheries and Ecological Services, Anchorage, Alaska, USA.

U.S. Fish and Wildlife Service (USFWS). 2017b. Alaska Regional Refuge Inventory and Monitoring Strategic Plan. USFWS, National Wildlife Refuge System, Alaska Region, Inventory and Monitoring Branch, Anchorage, Alaska, USA.

U.S. Fish and Wildlife Service (USFWS). 2018a. Yukon Flats National Wildlife Refuge. USFWS, Yukon Flats National Wildlife Refuge, Fairbanks, Alaska, USA. [online] URL: https://www.fws. gov/refuge/Yukon_Flats

U.S. Fish and Wildlife Service (USFWS). 2018b. Memorandum 11 April 2018. Guidance on the recent M-Opinion affecting the Migratory Bird Treaty Act. USFWS, Washington, D.C., USA.

U.S. Fish and Wildlife Service and National Marine Fisheries Service (USFWS and NMFS). 2014. Endangered, threatened, proposed, candidate, and delisted species in Alaska. (Updated May 13, 2014). U.S. Fish and Wildlife Service and National Marine Fisheries Service, Alaska, USA. [online] URL: https://www.fws. gov/alaska/fisheries/endangered/pdf/consultation_guide/4_species_list. pdf

Editor-in-Chief: Keith A.Hobson Subject Editor: Marcel Darveau
U.S. Geological Survey (USGS). 2012. Ecosystem science for now and the future: Cooperative Fish and Wildlife Research Units address real-world issues. USGS Factsheet, Reston, Virginia, USA.

U.S. North American Bird Conservation Initiative(U.S. NABCI). 2000. Bird Conservation Region descriptions: a supplement to the North American Bird Conservation Initiative Bird Conservation Regions map. U.S. Fish and Wildlife Service, Arlington, Virginia, USA. [online.] URL: https://digitalmedia.fws.gov/cdm/ref/ collection/document/id/1450

Walters, C. J., and C. S. Holling. 1990. Large-scale management experiments and learning by doing. Ecology 71:2060-2068. http:// dx.doi.org/10.2307/1938620

Warnock, N. 2017. Alaska Watchlist 2017. Audubon Alaska, Anchorage, Alaska, USA.

Wells, J., D. Stralberg, and D. Childs. 2018. Boreal forest refuge: conserving North America's bird nursery in the face of climate change. Boreal Songbird Initiative, Seattle, Washington, USA.

Wells, J. V., editor. 2011. Boreal birds of North America: a hemispheric view of their conservation links and significance. Studies in Avian Biology (no. 41), University of California Press, Berkeley, California, USA.

Werner, R. A., E. H. Holsten, S. M. Matsuoka, and R. E. Burnside. 2006. Spruce beetles and forest ecosystems in southcentral Alaska: a review of 30 years of research. Forest Ecology and Management 227:195-206. http://dx.doi.org/10.1016/j. foreco.2006.02.050

Wolken, J. M., T. N. Hollingsworth, T. S. Rupp, F. S. Chapin, III, S. F. Trainor, T. M. Barrett, P. F. Sullivan, A. D. McGuire, E. S. Euskirchen, P. E. Hennon, E. A. Beever, J. S. Conn, L. K. Crone, D. V. D'Amore, N. Fresco, T. A. Hanley, K. Kielland, J. J. Kruse, T. Patterson, E. A. G. Schuur, D. L. Verbyla, and J. Yarie. 2011. Evidence and implications of recent and projected climate change in Alaska's forest ecosystems. Ecosphere 2(11):124. http://dx.doi. org/10.1890/ES11-00288.1

Woodward, A., and E. A. Beever. 2011. Conceptual ecological models to support detection of ecological change on Alaska National Wildlife Refuges. Open-File Report 2011-1085. U.S. Geological Survey, Reston, Virginia, USA. http://dx.doi. org/10.3133/ofr20111085

Wu, J. X., C. B. Wilsey, L. Taylor, and G. W. Schuurman. 2018. Projected avifaunal responses to climate change across the U.S. National Park System. PLoS ONE 13(3):e0190557. http://dx.doi. org/10.1371/journal.pone.0190557

Wurtz, T. L., R. A. Ott, and J. C. Maisch. 2006. Timber harvests in interior Alaska. Pages 302-308 in F. S. Chapin, III, M. W. Oswood, K. Van Cleve, L. A. Viereck, and D. L. Verbyla, editors. Alaska's changing boreal forest. Oxford University Press, New York, New York, USA. 
Appendix 1. Important federal and state regulatory provisions that protect fish and wildlife habitats in boreal Alaska. A more complete digest of federal resource laws can be found at https://www.fws.gov/laws/lawsdigest/Resourcelaws.html.

\begin{tabular}{|c|c|c|}
\hline Statute or regulation & Legal reference $^{1}$ & General relevance \\
\hline \multicolumn{3}{|l|}{ Managing public lands } \\
\hline Administrative Procedure Act & 5 USC $\S 551$ et seq. & Provides public and judicial review of federal agency rulemaking and actions. \\
\hline $\begin{array}{l}\text { Alaska National Interest Lands } \\
\text { Conservation Act }\end{array}$ & 16 USC $\S 51$ & $\begin{array}{l}\text { Designated certain federal lands in Alaska as units of the National Park, } \\
\text { National Wildlife Refuge, Wild and Scenic Rivers, National Wilderness } \\
\text { Preservation and National Forest Systems. }\end{array}$ \\
\hline Alaska Native Claims Settlement Act & 43 USC $\S \S 1601-1629$ & $\begin{array}{l}\text { Authorized Alaska Natives to select and received title to public lands in Alaska } \\
\text { and nearly } \$ 1 \text { billion in settlement for aboriginal land claims in the state. Also } \\
\text { required the Secretary of Interior to withdraw up to 32.4-million ha of public } \\
\text { lands for consideration as additions to the national conservation system. }\end{array}$ \\
\hline
\end{tabular}

Conservation and Protection of

AS $\S \S 16.20 .020-080$

Alaska Fish and Game

Federal Land Policy and Management 43 USC $\S 1701$ et seq.; Act

43 CFR $§ 1600$

Land Use Planning and Classification AS § 38.04.065

National Park Service Organic Act 16 USC $\S \S 1-4$

National Wildlife Refuge

Administration Act

Parks and Recreation Facilities

AS $\S 41.21$

Sikes Act

16 USC $\S \S 670-670 f$

Wild and Scenic Rivers Act
16 USC $\S \S 668$ dd-668ee Designates a national network of lands and waters as wildlife refuges to protect and conserve fish and wildlife (including migratory birds) that are threatened with extinction, wildlife management areas, and waterfowl production areas.

Enabling statute for State Parks and Recreation Areas.

management statute that established multiple use, sustained yield, State statute for managing multiple-use lands through land use plans.

Established the National Park Service to oversee federal national parks, monuments, and reservations, in order to conserve scenery, natural and historic objects, and wildlife for future generations.

Primary agency

All federal agencies

Federal land agencies ${ }^{2}$

Federal land agencies

Alaska Department of Fish and Game

Bureau of Land Management

Alaska Department of Natural Resources

National Park Service

U.S. Fish and Wildlife

Service

Alaska Department of Natural Resources

Requires military installations to development and implement Integrated Natural Department of Defense Resources Management Plans in cooperation with the U.S. Fish and Wildlife

Service and state wildlife agencies

16 USC $§ 1271-1287$ Provides for a National Wild and Scenic Rivers System in which selected rivers Federal land agencies ${ }^{2}$ with "outstandingly remarkable" values are preserved to protect their water quality. 


\begin{tabular}{lll}
\hline Statute or regulation & Legal reference $^{1}$ & General relevance $^{-}$ \\
\hline Wilderness Act & 16 USC $\S 1131-1136$ & $\begin{array}{l}\text { Requires review of wilderness characteristics of each roadless area of 5,000 or } \\
\text { more acres within the National Wildlife Refuge, National Park, and National }\end{array}$ \\
& & $\begin{array}{l}\text { Forest systems for possible inclusion in the National Wilderness Preservation } \\
\text { System. }\end{array}$ \\
Managing birds, nests, and eggs & &
\end{tabular}

\section{Alaska Endangered Species Act}

Bald and Golden Eagle Protection Act

Endangered Species Act

Migratory Bird Treaty Act

\section{Managing bird habitats}

Alaska Forest Resources and

Practices Act and Regulations

Cooperative Forestry Assistance Act of 1978

Federal Power Act

16 USC $\S \S 791$ et seq.

Food, Conservation, and Energy Act Public Law 110-246 of 2008 (Farm Bill)

AS $\S \S 16.20 .180-$ 16.20.210 CFR $\S 22$ CFR $\S$ 20.20-20.26

AS $\S 41.17 ; 11$ AAC 95
Provides for the continued conservation, protection, restoration, and propagation of Alaskan species threatened with extinction.

16 USC $\S \S 668-668 \mathrm{~d} ; 50$ Regulates "take," possession, and transport of Bald and Golden Eagles, their nests, and eggs.

16 USC $\S \S 1531-1544$ Provides for conservation of species that are endangered or threatened throughout all or a significant portion of their range and conservation of the ecosystems on which they depend; prohibits "take" of listed species and destruction or adverse modification of their habitats. ${ }^{4}$

16 USC $\$ \S 703-712 ; 50$ Implements the terms of U.S. treaty conventions with Great Britain (Canada), Mexico, Japan, and Russia; prohibits "take" of native migratory birds, their nests, and eggs. ${ }^{5}$ The implementing regulations describe allowable harvest methods and means, and, at 50 CFR $\S 20.21(\mathrm{j})$, restrict the use of lead shot in taking ducks, geese, swans, and other migratory game birds.

Governs timber harvesting, reforestation, and roadbuilding on state, private, and municipal lands. Forest management standards on federal land must meet or exceed the standards; establishes nonpoint source pollution and fish habitat protection standards under state law.

Assists state forestry agencies with forest stewardship programs on private, state, local, and other nonfederal forest lands. Programs address topics such as increased timber production, forest disease management, improving fish and wildlife habitat, and conservation of forest land.

Coordinates federal agency review and licensing of hydropower projects. Equal consideration is to be given to power and development, energy conservation, protection, mitigation of damage to and enhancement of fish and wildlife, protection of recreational opportunities, and preservation of other aspects of environmental quality.

Established federal financial incentives for bioenergy using forest materials, as well as conservation of fish and wildlife on private lands. Also provided support for development of state Forest Action Plans, analyses of forest conditions and trends, and designation of priority forest landscape areas to address threats and improve health.
Alaska Department of Fish and Game

U.S. Fish and Wildlife Service

U.S. Fish and Wildlife Service, National Marine Fisheries Service

U.S. Fish and Wildlife Service

Alaska Department of Natural Resources

U.S. Forest Service; Alaska Department of Natural

Resources

\section{Federal Energy Regulatory} Commission

U.S. Forest Service, Alaska Department of Natural Resources 


\begin{tabular}{l}
\hline Statute or regulation \\
\hline Healthy Forests Reserve Program \\
National Environmental Policy Act \\
Managing birds habitats: wetlands
\end{tabular}

Anadromous Fish Act

Clean Water Act

Fishway Act

Fish and Wildlife Coordination Act

Rivers and Harbors Act, Section 10

33 USC $§ 403$

\section{Conservation funding}

Federal Aid in Sport Fish Restoration 16 USC. $\S \S 777-7771$ Act (Dingell-Johnson Act)

Legal reference

16 USC $\S \S 6571-6578$

42 USC $\S \S 4321$ et seq

AS $\S 16.05 .871-901$

33 USC $\S 1251-1387$

AS $§ 16.05 .841$

16 USC $\S 661-667 e$
General relevance

Primary agency

Seeks to restore and enhance forest ecosystems on private land to promote recovery of threatened and endangered species, improve biodiversity, and enhance carbon sequestration. Voluntary incentive programs for private landowners to conserve their working agricultural lands, wetlands, grasslands, and forest lands.

Requires federal agencies to describe and assess environmental effects of development proposals, consider alternatives, seek public input prior to agency decisions, and to provide necessary mitigation for environmental effects.

All federal agencies

atural Resource

Conservation Service
Requires permit approval from ADFG before altering or affecting "the natural flow or bed" of an identified anadromous fish stream.

Alaska Department of Fish and Game

Establishes water quality standards and regulates the discharge of pollutants an dredged or fill material into waters of the U.S., including wetlands.

Requires notification and authorization from ADFG for activities within or across a stream used by fish Engineers, Environmental Protection Agency

Alaska Department of Fish and Game

Requires federal agencies to consult with the U.S. Fish and Wildlife Service, the Federal Energy Regulatory National Marine Fisheries Service, and state wildlife agencies for activities that affect or modify any stream or body of water, to minimize adverse impacts on fish and wildlife resources and habitat; generally undertaken as part of Clean Water Act, 404 of the Clean Water Act, NEPA, or Federal Power Act project reviews.

Prohibits obstruction or alteration of navigable waters of the US without a permit from the Corps of Engineers.

\section{Commission, National} Marine Fisheries Service, U.S. Army Corps of Engineers, U.S. Fish and Wildlife Service Army Corp of Engineers
Excise taxes on sport fishing equipment to provide federal aid funding to states U.S. Fish and Wildlife to manage and restore marine and freshwater sport fish populations, as well as to Service support aquatic education, wetlands restoration, and boat safety and sanitation. Administered by the Wildlife and Sport Fish Restoration program. 


\begin{tabular}{|c|c|c|c|}
\hline Statute or regulation & Legal reference $^{1}$ & General relevance & Primary agency \\
\hline $\begin{array}{l}\text { Federal Aid in Wildlife Restoration } \\
\text { Act (Pittman-Robertson Act) }\end{array}$ & 16 USC $\S \S 669-669 \mathrm{k}$ & $\begin{array}{l}\text { Excise taxes on firearms, ammunition, and archery equipment go to states for } \\
\text { projects to restore, conserve, manage, and enhance wild gamebirds and } \\
\text { mammals and their habitats. Funding is administered through the USFWS } \\
\text { Wildlife and Sport Fish Restoration program (WSFR). Unused monies transfer } \\
\text { in part to the Neotropical Migratory Bird Conservation Act. Interest on holdings } \\
\text { is available as funds for the North American Wetland Conservation Act. It is } \\
\text { important to note that funds supporting State Wildlife Grants (SWG) and a } \\
\text { national conservation strategy of State Wildlife Action plans (also administered } \\
\text { through the WSFR) rely upon annual congressional appropriations from the U.S. } \\
\text { Treasury. }\end{array}$ & $\begin{array}{l}\text { U.S. Fish and Wildlife } \\
\text { Service }\end{array}$ \\
\hline $\begin{array}{l}\text { Fish and Wildlife Conservation Act } \\
\text { of } 1980\end{array}$ & 16 USC $\S \S 2901-2912$ & $\begin{array}{l}\text { Provides financial and technical assistance to states for to develop and } \\
\text { implement conservation plans (e.g., State Wildlife Action Plans) and programs } \\
\text { for nongame fish and wildlife. Encourages all federal departments and agencies } \\
\text { to conserve and promote conservation of nongame fish and wildlife and their } \\
\text { habitats. }\end{array}$ & $\begin{array}{l}\text { U.S. Fish and Wildlife } \\
\text { Service }\end{array}$ \\
\hline $\begin{array}{l}\text { Neotropical Migratory Bird } \\
\text { Conservation Act }\end{array}$ & 16 USC $\S \S 6101-6109$ & $\begin{array}{l}\text { Federal grants that support and foster international cooperation and initiatives to } \\
\text { perpetuate healthy migratory bird populations throughout the Western } \\
\text { hemisphere. }\end{array}$ & $\begin{array}{l}\text { U.S. Fish and Wildlife } \\
\text { Service }\end{array}$ \\
\hline $\begin{array}{l}\text { North American Wetlands } \\
\text { Conservation Act }\end{array}$ & 16 USC $\S \S 4401-4412$ & $\begin{array}{l}\text { Federal funding and administrative direction to implement the North American } \\
\text { Waterfowl Management Plan. }\end{array}$ & $\begin{array}{l}\text { U.S. Fish and Wildlife } \\
\text { Service }\end{array}$ \\
\hline Partners for Fish and Wildlife Act & 16 USC $\S \S 3771-3774$ & $\begin{array}{l}\text { Provides for the restoration, enhancement, and management of fish and wildlife } \\
\text { habitats on private land through the Partners for Fish and Wildlife Program. }\end{array}$ & $\begin{array}{l}\text { U.S. Fish and Wildlife } \\
\text { Service }\end{array}$ \\
\hline
\end{tabular}

\section{${ }^{1} \mathrm{AAC}=$ Alaska Administrative Code, AS = Alaska Statutes, CFR = Code of Federal Regulations, USC = United States Code}

${ }^{2}$ Bureau of Land Management, National Park Service, U.S. Fish and Wildlife Service, and U.S. Forest Service

${ }^{3}$ BGEPA defines "take" as pursue, shoot, shoot at, poison, wound, kill, capture, trap, collect, destroy, molest, or disturb. "Disturb" is further defined as to agitate or bother to a degree that causes, or is likely to cause injury, decrease productivity, or nest abandonment

${ }^{4}$ ESA defines "take" as to "harass, harm, pursue, hunt, shoot, wound, kill, trap, capture, or collect or attempt to engage in any such conduct." 16 USC § 1532(19).

${ }^{5}$ MBTA makes it unlawful, without a permit, to "pursue, hunt, take, capture, kill”, sell, buy, or transport "any migratory bird or any part, nest, or egg thereof." 